\title{
Additional Results of Glaze Icing Scaling in SLD Conditions
}

Jen-Ching Tsao

Ohio Aerospace Institute, Brook Park, Ohio 


\section{NASA STI Program . . . in Profile}

Since its founding, NASA has been dedicated to the advancement of aeronautics and space science. The NASA Scientific and Technical Information (STI) Program plays a key part in helping NASA maintain this important role.

The NASA STI Program operates under the auspices of the Agency Chief Information Officer. It collects, organizes, provides for archiving, and disseminates NASA's STI. The NASA STI Program provides access to the NASA Technical Report Server-Registered (NTRS Reg) and NASA Technical Report ServerPublic (NTRS) thus providing one of the largest collections of aeronautical and space science STI in the world. Results are published in both non-NASA channels and by NASA in the NASA STI Report Series, which includes the following report types:

- TECHNICAL PUBLICATION. Reports of completed research or a major significant phase of research that present the results of NASA programs and include extensive data or theoretical analysis. Includes compilations of significant scientific and technical data and information deemed to be of continuing reference value. NASA counter-part of peer-reviewed formal professional papers, but has less stringent limitations on manuscript length and extent of graphic presentations.

- TECHNICAL MEMORANDUM. Scientific and technical findings that are preliminary or of specialized interest, e.g., "quick-release" reports, working papers, and bibliographies that contain minimal annotation. Does not contain extensive analysis.
- CONTRACTOR REPORT. Scientific and technical findings by NASA-sponsored contractors and grantees.

- CONFERENCE PUBLICATION. Collected papers from scientific and technical conferences, symposia, seminars, or other meetings sponsored or co-sponsored by NASA.

- SPECIAL PUBLICATION. Scientific, technical, or historical information from NASA programs, projects, and missions, often concerned with subjects having substantial public interest.

- TECHNICAL TRANSLATION. Englishlanguage translations of foreign scientific and technical material pertinent to NASA's mission.

For more information about the NASA STI program, see the following:

- Access the NASA STI program home page at http://www.sti.nasa.gov

- E-mail your question to help@sti.nasa.gov

- $\quad$ Fax your question to the NASA STI Information Desk at 757-864-6500

- Telephone the NASA STI Information Desk at 757-864-9658

- Write to:

NASA STI Program

Mail Stop 148

NASA Langley Research Center Hampton, VA 23681-2199 


\section{Additional Results of Glaze Icing Scaling in SLD Conditions}

Jen-Ching Tsao

Ohio Aerospace Institute, Brook Park, Ohio

Prepared for the

8th Atmospheric and Space Environments Conference

sponsored by AIAA

Washington, D.C., June 13-17, 2016

Prepared under Contract NCC13BA10B

National Aeronautics and

Space Administration

Glenn Research Center

Cleveland, Ohio 44135 


\section{Acknowledgments}

This work is supported by the Advanced Air Transport Technology (AATT) Project in the NASAAd-vanced Air Vehicles Program, and is in response to the Airframe Icing Technical Challenge. The author is supported currently under a NASA Glenn ARTS contract. Special thanks are extended to Dr. Ron Colantonio and Mary Wadel, Chief of the NASA Glenn Icing Branch, for their supports of these tests, the imaging specialist Mr. Quentin Schwinn for his technical support in providing all 2-D and 3-D ice shapes from 3-D scanner data, and the IRT personnel for their continuing excellent technical support of the testing effort.

This report contains preliminary findings, subject to revision as analysis proceeds.

Trade names and trademarks are used in this report for identification only. Their usage does not constitute an official endorsement, either expressed or implied, by the National Aeronautics and Space Administration.

Level of Review: This material has been technically reviewed by NASA expert reviewer(s).

Available from

NASA STI Program

Mail Stop 148

NASA Langley Research Center

Hampton, VA 23681-2199
National Technical Information Service 5285 Port Royal Road Springfield, VA 22161 703-605-6000

This report is available in electronic form at http://www.sti.nasa.gov/ and http://ntrs.nasa.gov/ 


\title{
Additional Results of Glaze Icing Scaling in SLD Conditions
}

\author{
Jen-Ching Tsao \\ Ohio Aerospace Institute \\ Brook Park, Ohio 44142
}

\begin{abstract}
New guidance of acceptable means of compliance with the super-cooled large drops (SLD) conditions has been issued by the U.S. Department of Transportation's Federal Aviation Administration (FAA) in its Advisory Circular AC 25-28 in November 2014. The Part 25, Appendix O is developed to define a representative icing environment for super-cooled large drops. Super-cooled large drops, which include freezing drizzle and freezing rain conditions, are not included in Appendix C.

This paper reports results from recent glaze icing scaling tests conducted in NASA Glenn Icing Research Tunnel (IRT) to evaluate how well the scaling methods recommended for Appendix C conditions might apply to SLD conditions. The models were straight NACA 0012 wing sections. The reference model had a chord of $72 \mathrm{in.}$ and the scale model had a chord of $21 \mathrm{in.} \mathrm{Reference} \mathrm{tests} \mathrm{were} \mathrm{run}$ with airspeeds of 100 and $130.3 \mathrm{kn}$ and with MVD's of 85 and $170 \mu \mathrm{m}$. Two scaling methods were considered. One was based on the modified Ruff method with scale velocity found by matching the Weber number $\mathrm{We}_{L}$. The other was proposed and developed by Feo specifically for strong glaze icing conditions, in which the scale liquid water content and velocity were found by matching reference and scale values of the nondimensional water-film thickness expression and the film Weber number $\mathrm{We}_{f}$. All tests were conducted at $0^{\circ}$ AOA. Results will be presented for stagnation freezing fractions of 0.2 and 0.3 .

For nondimensional reference and scale ice shape comparison, a new post-scanning ice shape digitization procedure was developed for extracting 2-D ice shape profiles at any selected span-wise location from the high fidelity 3-D scanned ice shapes obtained in the IRT.
\end{abstract}

\section{Nomenclature}

$A_{c} \quad$ Accumulation parameter, dimensionless

$b \quad$ Relative heat factor, dimensionless

c Airfoil chord, $\mathrm{cm}$

$d \quad$ Cylinder radius or twice the leading-edge nose radius of airfoil, $\mathrm{cm}$

$h \quad$ Water film thickness, $\mathrm{cm}$

$K_{0} \quad$ Modified inertia parameter, dimensionless

LWC Cloud liquid-water content, $\mathrm{g} / \mathrm{m}^{3}$

MVD $\quad$ Water droplet median volume diameter, $\mu \mathrm{m}$

$n \quad$ Local freezing fraction, dimensionless

$n_{0} \quad$ Stagnation freezing fraction, dimensionless

Re Reynolds number of model, dimensionless

$\mathrm{Re}_{\delta} \quad$ Reynolds number of water drop, dimensionless

$t_{\text {st }} \quad$ Static temperature, ${ }^{\circ} \mathrm{C}$

$V \quad$ Air velocity, kt

We Weber number based on droplet size and water properties, dimensionless

$\mathrm{We}_{c} \quad$ Weber number based on model size and air properties, dimensionless

$\mathrm{We}_{h} \quad$ Weber number based on water-film thickness and air freestream velocity, dimensionless

$\mathrm{We}_{f} \quad$ Weber number based on water-film thickness and film velocity, dimensionless 


$\begin{array}{ll}\mathrm{We}_{L} & \text { Weber number based on model size and water properties, dimensionless } \\ \mathrm{We}_{t} & \text { Weber number based on water-film thickness and air velocity and properties, dimensionless } \\ \mathrm{We}_{\delta} & \text { Weber number based on droplet size and air properties, dimensionless } \\ \beta_{0} & \text { Collection efficiency at stagnation line, dimensionless } \\ \phi & \text { Droplet energy transfer parameter, }{ }^{\circ} \mathrm{C} \\ \tau & \text { Accretion time, min } \\ \text { Subscripts } \\ R & \text { Reference } \\ S & \text { Scale } \\ f & \text { Water film } \\ \text { st } & \text { Static } \\ \text { tot } & \text { Total }\end{array}$

\section{Introduction}

The latest aircraft icing certification standards have included testing with super-cooled large drops in addition to the FAA Part 25 Appendix C (Ref. 1) icing conditions. With the updated standards test facilities will need to provide acceptable means of compliance for testing at actual or simulated SLD conditions. All existing icing wind tunnel cloud calibrations will need to be expanded to include the SLD conditions in order to meet the certification requirements. In addition, appropriate scaling methods are needed both for conducting specific SLD-cloud testing on models smaller than full scale and for simulating SLD drop size effects on ice accretion with tests using Appendix C conditions. Recent SLD scaling studies in the IRT (Refs. 2 to 8 ) had shown that acceptable scaling results could be achieved by matching the $\beta_{0}, A_{c}, n_{0}$ and $\mathrm{We}_{L}$. With scale model size selected, by matching scale and reference values of $\mathrm{We}_{L}$ the scale velocity can be determined. By matching $\beta_{0}$ the scale $M V D$ can be found. Anderson (Ref. 2) also showed that the effects of temperature and $L W C$ are not independent, but interact through the freezing fraction. Therefore, with scale $L W C$ chosen, by matching $n_{0}$ the scale temperature can be calculated. Finally, by matching $A_{c}$ the scale time can be established. For the scale test, then, only temperature, velocity, $M V D$ and time have to be calculated from the known (reference) values of the similarity parameters.

The results presented here are part of an effort to develop appropriate scaling methods for super-cooled large drops in glaze icing conditions. During glaze-ice accretion water does not freeze immediately in the zone of impingement. The characteristics of the resulting layer of surface runback water are believed to influence the shape of the accreted ice to some extent and are the subject of a number of ongoing studies. Bilanin (Ref. 9) and Bilanin and Anderson (Ref. 10) advocated adding another similarity parameter, the Weber number, to scaling requirements to address surface-water effects. Two forms of the Weber number that might be applied include that based on the droplet MVD and water properties (We) and one based on model size and air properties $\left(\mathrm{We}_{c}\right)$. A third Weber number was suggested by Kind (Ref. 11); this one was based on the thickness of the water film at the leading edge and air properties $\left(\mathrm{We}_{t}\right)$.

Anderson and Ruff (Ref. 12) and Anderson (Ref. 13) reported the best scaling results for glaze ice were achieved when a compromise between constant We and constant Re was used with the modified Ruff method. A possible explanation for this result comes from studies of droplet-surface impact (Ref. 14) for non-icing applications. These studies correlated splashing effects with a $K$ factor that depended only on $\mathrm{We}$ and $\mathrm{Re}_{\delta}$. Other surface-tension effects such as water-film breakup and rivulet formation are also We and Re dependent. 
Finally, in a recent study at above-freezing temperatures, Feo and Urdiales (Ref. 15) measured the water-film thickness, $h$, for heavy-rain conditions. The nondimensional film thickness, $h / d$, was found to correlate with We and $\operatorname{Re}_{\delta}$. The authors suggested that $h / d$ might itself serve as an appropriate similarity parameter for scaling studies. Although spray characteristics for that study were very different from Appendix $\mathrm{C}$ conditions, the heavy-rain $h / d$ was evaluated as a similarity parameter in studies comparing how methods to select scale velocity affected ice shape (Refs. 12 and 13). However, matching the scale and reference $h / d$ of Feo and Urdiales gave scale ice shapes that were generally a poorer match of the reference than did other methods of finding scale velocity. Later, Feo (Ref. 16) measured the thickness of the water film for $M V D$ and $L W C$ conditions near those in an icing cloud and correlated the results with $L W C$ and Re. In the study he suggested another Weber number based on the water film thickness and water properties $\left(\mathrm{We}_{h}\right)$ as a similarity parameter for scaling studies. Preliminary studies of the constantwater-film-thickness and constant-Weber-number methods in scaling tests using this new $h / d$ correlation have been made (Ref. 17) and the limited results compared reasonably well with those using the Weber number We.

In several more recent studies (Refs. 18 and 19) similarity parameters derived from surface water film dynamics were proposed. The film Weber Number $\left(\mathrm{We}_{f}\right)$ as defined before (Ref. 20) was introduced with the nondimensional film thickness, being both required to be matched at scale and reference conditions. The nondimensional film thickness $(h / d)$ expressions were obtained from two sets of experiments that were conducted in one of INTA'S Low Speed Tunnels; one being for Appendix C (Refs. 16 and 21) and the other for SLD droplets (Ref. 22). In addition, Feo has also suggested a slightly different approach from the modified Ruff method as recommended in References 3 and 4 to determine appropriate scale test conditions. Three of the similarity expressions are from well-established methods (droplets' trajectories, freezing fraction and ice accumulation) and the other two requirements were obtained by requiring $\mathrm{We}_{f}=$ const. and $(h / d)=$ const, the last one being taken from experiments. Depending on the expression of $(h / d)$ used, we have results either for Appendix C or SLD droplets. However there was very little ice shape data available in the strong glaze icing regime of $n_{0}<0.3$ to adequately evaluate the proposed scaling methods.

The present study will continue to evaluate both the constant $\mathrm{We}_{L}$ and the constant $\left(\mathrm{We}_{f}\right.$ and $h / d$ ) methods in strong glaze icing conditions with SLD reference drop sizes in the range of 70 to $170 \mu \mathrm{m}$ which is the current largest $M V D$ size calibrated in the IRT. To better characterize and document those SLD glaze ice shapes, a new procedure of extracting multiple 2-D digitized ice shapes from a 3-D scan ice shape data was developed and has been fully implemented and utilized in all NASA icing research tests conducted in the IRT since 2014. A brief description of the post-scan ice shape extraction process will be given later in the Test Description section. As for the nondimensional 2-D ice shape comparison commonly used by icing scaling method analysis the traditional cross-sectional hand tracings will be replaced by 2-D digitized ice shape profiles obtained from a 3-D laser scan. In addition, a 3-D ice shape image from each laser scanning around the mid-span section of the model will also be provided to highlight the 3-D nature of the ice accretion observed in SLD icing.

\section{Similarity Parameters}

The similarity parameters used in this study were based on the work originally done by Ruff (Ref. 23). The current scaling method (i.e., the modified Ruff method) required matching scale and reference values of the key similarity parameters, $\beta_{0}, A_{c} n_{0}$ and $\mathrm{We}_{L}$ with scale $L W C$ chosen at user's convenience. The equations for the similarity parameters will be presented here without much discussion. Therefore, readers who are interested in the physical descriptions and detailed derivations of these parameters are referred to References 2, 3, and 18 and the references given therein. 
To maintain the droplet trajectory similitude, Langmuir and Blodgett (Ref. 24) introduced the modified inertia parameter, $K_{0}$, defined as

$$
K_{0}=\frac{1}{8}+\frac{\lambda}{\lambda_{\text {Stokes }}}\left(K-\frac{1}{8}\right)
$$

In Equation (1), $K$ is the inertia parameter,

$$
K=\frac{\rho_{w} \mathrm{MVD}^{2} V}{18 d \mu}
$$

Departing slightly from Langmuir and Blodgett in this study, $d$ is twice the leading-edge radius of curvature for airfoils. For the NACA 0012 airfoil model, a leading-edge radius of $0.0158 c$ was used (see Abbott and von Doenhoff (Ref. 25)), where $c$ is the airfoil chord. $\lambda / \lambda_{\text {Stokes }}$ is the droplet range parameter, defined as the ratio of actual droplet range to that if Stokes drag law for solid-spheres applied. It is a function only of the droplet Reynolds number, $\operatorname{Re}_{\delta}$.

$$
\operatorname{Re} \delta=\frac{V \operatorname{MVD} \rho}{\mu}
$$

This study used a curve fit to Langmuir and Blodgett's tabulation of the range parameter as given in the following expression:

$$
\frac{\lambda}{\lambda_{\text {Stokes }}}=\frac{1}{\left(0.8388+0.001483 \mathrm{Re}_{\delta}+0.1847 \sqrt{\mathrm{Re}_{\delta}}\right)}
$$

Of more practical interest than $K_{0}$ is the collection efficiency at the stagnation point, $\beta_{0}$, which was shown by Langmuir and Blodgett to be a function only of $K_{0}$,

$$
\beta_{0}=\frac{1.40\left(K_{0}-\frac{1}{8}\right)^{.84}}{1+1.40\left(K_{0}-\frac{1}{8}\right)^{.84}}
$$

Thus the droplet trajectory similarity is satisfied if $K_{0, S}=K_{0, R}$ (so does $\beta_{0, S}=\beta_{0, R}$ ), and the scale drop size, i.e., scale $M V D$, is determined. To ensure water-catch similarity, the accumulation parameter is introduced:

$$
A_{c}=\frac{L W C V \tau}{d \rho_{i}}
$$

If all the water impinging on the leading edge freezes at that location and the leading-edge collection efficiency is 100 percent, $A_{c}$ directly becomes a measure of the normalized thickness of ice that will accrete. The scale accretion time can be found from $A_{c, S}=A_{c, R}$. However if it is not possible to find scaled conditions that permit a match of $K_{0}$ (and therefore $\beta_{0}$ ) and $A_{c}$ separately, it is recommended that the product of $\beta_{0} A_{c}$ be matched provided the two collection efficiencies, $\beta_{0, S}$ and $\beta_{0, R}$, be within 10 percent, see Reference 3 for details. 
The rate at which the water freezes on a surface depends on the magnitude of local heat transfer imbalance. For glaze ice, it is known that the fraction of water that freezes is less than unity, and the motion of unfrozen surface water can have an effect on the resulting ice shape. Therefore, it is important to maintain surface energy and surface-water dynamics similarities for glaze ice accretions. The freezing fraction is formally defined as the ratio of the amount of water that freezes at a given surface location to the total amount of water that impinges at that location. From Messinger's (Ref. 26) steady-state surface energy balance analysis, the stagnation point freezing fraction can be written as

$$
n_{0}=\frac{c_{p, w s}}{\Lambda_{f}}\left(\phi+\frac{\theta}{b}\right)
$$

The key terms in this formulation include $\phi$ and $\theta$, which have dimensions of temperature and relate to the water drop energy transfer and air energy transfer, and $b$, the relative heat factor, which was first introduced by Tribus, et al. (Ref. 27)

$$
\begin{gathered}
\varphi=t_{f}-t_{\mathrm{st}}-\frac{V^{2}}{2 c_{p, w s}} \\
\theta=\left(t_{s}-t_{\mathrm{st}}-r \frac{V^{2}}{2 c_{p}}\right)+\frac{h_{G}}{h_{c}}\left(\frac{\frac{p_{w w}}{T_{\mathrm{st}}}-\frac{p_{\mathrm{tot}}}{T_{\mathrm{tot}}} \frac{p_{w}}{p_{\mathrm{st}}}}{\frac{1}{p_{\mathrm{tot}}}-\frac{p_{w w}}{T_{\mathrm{tot}}}}\right) \Lambda_{v} \\
b=\frac{L W C V \beta_{0} c_{p, w s}}{h_{c}}
\end{gathered}
$$

Equation (9) from Ruff (Ref. 23) has included compressibility effects. Various incompressible forms of $\theta$ have also been used by Charpin and Fasso (Ref. 28) and others; however, the differences are not significant mainly due to the fact that, for most icing conditions, the Mach number is relatively low. Since only limited combinations of MVDs and $L W C \mathrm{~s}$ in the SLD regime are currently available in the IRT, the stagnation point freezing fraction is matched to find the scale static temperature instead of the scale $L W C$ value in this study.

Because the original Ruff method does not restrict the value of scale velocity, an additional similarity parameter can be used to determine $V_{S}$. In 2003 Anderson and Tsao (Ref. 29) had provided experimental evidence from past studies to show that a similarity parameter dependent on the ratio $V^{x} c^{y} / \sigma^{z}$ must be included in scaling methodology to account for surface-water dynamics effect in glaze ice accretions, although the powers $x, y$, and $z$ are not yet determined. The length may not be chord itself but rather some physical characteristic $L$ related to chord; for example, the water-film thickness. Likewise, the velocity could also be of the water-film which is related to $V$. Thus a Weber number based on $L$ and $V$

$$
\mathrm{We}_{L}=\frac{V^{2} L \rho_{w}}{\sigma}
$$


has been suggested as a potential additional similarity parameter to supplement Ruff's basic scaling method. Studies by Bartlett (Refs. 30 and 31) and Oleskiw, et al. (Ref. 32) found no measurable effect of altitude pressure on ice shape. These observations suggest that water density is a better choice than air density for Equation (11). In this study the $\mathrm{We}_{L}$ utilizes twice the leading-edge nose radius of the airfoil as the characteristic length $L$ :

$$
\mathrm{We}_{L}=\frac{V^{2} d \rho_{w}}{\sigma}
$$

The scale velocity found from matching $\mathrm{We}_{L, S}=\mathrm{We}_{L, R}$ is

$$
V_{S}=V_{R}\left(\frac{d_{R}}{d_{S}}\right)^{1 / 2}
$$

The other method proposed by Feo (Ref. 20) involved matching simultaneously the water-film thickness and a Weber number that used the water-film velocity and water-film thickness:

$$
\mathrm{We}_{f}=\frac{V_{f}^{2} h_{f} \rho_{w}}{\sigma}
$$

By equating shear stresses at the air-water interface, the water-film velocity can be written as

$$
V_{f}=\operatorname{Re}^{1 / 2}\left(\frac{h_{f}}{d}\right) V
$$

When Equation (15) is substituted into Equation (14) and letting scale and reference values of $\left(h_{f} / d\right)$ be equated while matching $\left(\mathrm{We}_{f}\right)_{S}=\left(\mathrm{We}_{f}\right)_{R}$, the expression becomes

$$
\left(\operatorname{ReWe}_{L}\right)_{S}=\left(\operatorname{ReWe}_{L}\right)_{R}
$$

From Equation (16) the scale velocity is

$$
V_{S}=V_{R}\left(\frac{d_{R}}{d_{S}}\right)^{2 / 3}
$$

The Reynolds number Re shown above is also based on the twice the nose radius of the airfoil:

$$
\operatorname{Re}=\frac{V d \rho}{\mu}
$$


For large SLD drop sizes where drop impact could strongly interact with the surface air-driven film flow, the best correlation of the experimental film thickness data (Ref. 22) was found to be

$$
h_{f} / d \propto\left(\frac{L W C}{\rho_{w}}\right)^{1 / 2} \operatorname{Re}^{-1 / 4} \mathrm{We}_{c}^{-1 / 2}\left(\mathrm{We}_{\delta}^{1 / 2} \mathrm{Re}_{\delta}^{-1}\right)
$$

By matching scale and reference values of nondimensional film thickness $\left(h_{f} / d\right)$, a scale $L W C$ was determined

$$
L W C_{S}=L W C_{R}\left(\frac{d_{R}}{d_{S}}\right)^{-0.7}
$$

\section{Test Description}

\section{Facility, Model, and Procedures}

The scaling tests were performed in the NASA Glenn Icing Research Tunnel (IRT). The IRT is a closed-loop, refrigerated, sea level tunnel with a 6 by $9 \mathrm{ft}$ rectangular test section. The icing cloud is generated by operating 10 spray bars with two different air-atomizing nozzle types: Mod1 (lower water flow rates) and Standard (higher water flow rates). It is possible to turn on only the Mod1 nozzles, only the Standard nozzles or both (with the same air pressure). In 2010, NASA Glenn Research Center received stimulus fund for improvements to the Icing Research Tunnel. Both the original 1940s refrigeration plant and the 1999 flat panel heat exchanger have been replaced in 2011. A subsequent full cloud calibration of the IRT was completed at the end of January 2012 (Ref. 33).

The IRT cloud calibrations for both Appendix C and SLD conditions used for these tests were performed in December 2013 to February 2014 (Ref. 34) and January 2015. The $L W C$ measurements were made using the Multi-Element water content sensor (commonly known as Multi-Wire sensor) from Science Engineering Associates, Inc. (SEA) as reported recently (Ref. 35). However, during the January 2015 interim calibration there was some correction made to Standard and Mod1 nozzle $L W C$ values obtained from the IRT 2015 spray-bar calculator due to new 3-D Etot corrections from Rigby, et al. (Ref. 36) but no change was made to $M V D$ calculations. The $M V D$ s reported in this paper are based on an analysis of the $M V D$ calibration data completed in February 2014. In addition, because only some $M V D$ $L W C$ combinations at speeds of $100,150,200$, and $250 \mathrm{kt}$ have been calibrated to date in the SLD regime, SLD reference tests are constrained to these specific conditions or preferably chosen within the calibrated envelope.

The models were NACA 0012 airfoil sections with chords of 72 and 21 in. scale-to-reference model size ratio was 1:3.4. The 72-in.-chord airfoil is pictured in Figure 1(a). It was a full-span, aluminum model at $0^{\circ}$ angle of attack and served as the reference model. The 21 -in-chord scale model was also full span and made of aluminum as shown in Figure 1(b). Horizontal lines at the leading edge were drawn at the tunnel vertical center (model mid span) and \pm 1.0 in. from the center to locate ice-tracing templates. Vertical lines were also placed at increments of $1.0 \mathrm{in}$. (labeled in inches on the model), measured along the surface from the stagnation line. These marks helped to identify sites on the model for close-up photographs of feather structure details. 


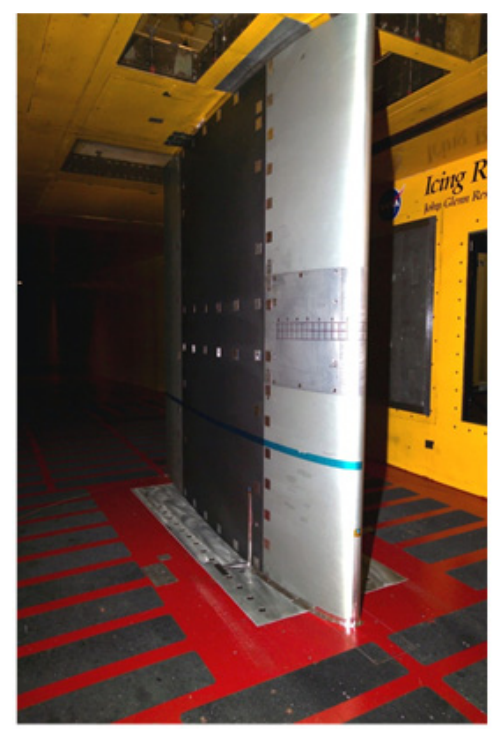

(a) 72-in-Chord Full-Span Model

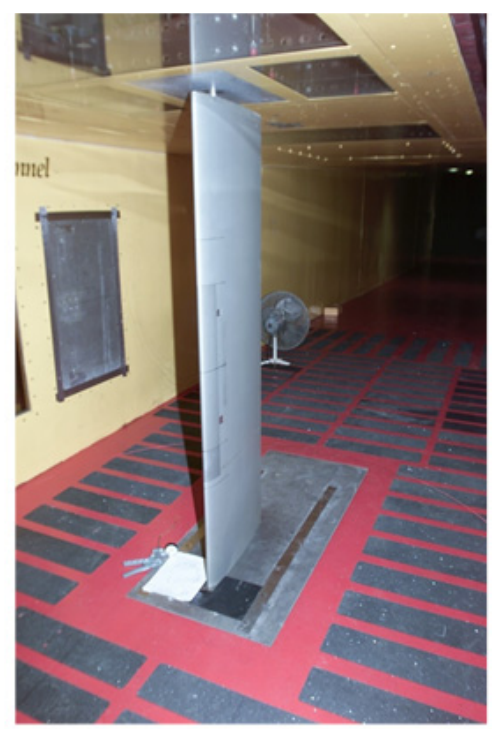

(b) 21-in-Chord Full-Span Models

Figure 1.-NACA 0012 airfoils installed in IRT test section: (a) the reference model and $(b)$ the scale model.

In preparing for a test, the temperature and airspeed in the test section and the air and water pressures on the spray manifolds were set. When those conditions had stabilized, the spray nozzle valves were opened to initiate the spray. The spray was timed for the required duration, and then turned off. Immediately after the completion of a glaze icing spray, the fan was brought down nearly to a full stop to maintain a wind tunnel airspeed of 5 to $10 \mathrm{kt}$ while keeping the air static temperature around $-4{ }^{\circ} \mathrm{C}$ to avoid melting of the glaze ice shape. The researchers entered the test section to first document the ice shape with a hand-held digital camera. The iced airfoil was further painted using an alcohol-based titanium dioxide paint. A commercially available articulated-arm, the ROMER Absolute Arm, 3-D laser scanning system was placed in the IRT test section upstream of the airfoil model. A detailed 3-D ice shape scan was then made of the front 10 to 15 percent chord of the iced airfoil leading-edge region (in the stream-wise direction). Each scan was 4-in. wide roughly (in the span-wise direction) and was performed at the mid-span location of the model (i.e., 36 in. above the floor).

The ice shapes so recorded were further digitized using the 2-D section cut feature in Geomagic Studio software (Ref. 37) and the output feature of 2-D outline control point coordinates from Rhinoceros software (Ref. 38). The ice shape comparison results presented in this study were obtained from three IRT test entries in March-April, October and December 2014, two entries in January and February 2015, and one entry in January 2016.

\section{Uncertainty Analysis}

Estimates of the uncertainty in the reported average conditions were made by considering inherent errors of instruments, temporal fluctuation and spatial variation of the instrument readings in the test section, and uncertainty in tunnel calibration of $M V D$ and $L W C$. Recorded air temperature was believed to be accurate to $\pm 0.2^{\circ} \mathrm{C}$, although variations during the period of an icing spray increases the uncertainty for reported average temperatures to about $\pm 0.5^{\circ} \mathrm{C}$. The uncertainty in air velocity was estimated to be $\pm 1 \mathrm{~m} / \mathrm{s}$ (i.e., $2 \mathrm{kt}$ ). For Appendix-C conditions the net uncertainty in $M V D$ was estimated at \pm 10 percent. For SLD conditions it may have been as much as \pm 20 percent. These uncertainties are not referenced to an absolute value of $M V D$, which is unknown. Repeatability and scatter in the $L W C$ calibration data suggests the uncertainty is about \pm 10 percent for Appendix- $C$ and is about \pm 20 percent for SLD conditions. 
The test-parameter uncertainties were used to approximate the following uncertainties in the similarity parameters. For the SLD test conditions used in this paper, the uncertainties were: 1.9 percent in $\beta_{0}, 20$ percent in $A_{c}, 18.5$ percent in $n_{0}, 0.9$ percent in Re, 1.9 percent in $\mathrm{We}_{L}, 14.2$ percent in $h_{f} / d$, and 42.4 percent in $\mathrm{We}_{f}$. For the Appendix-C test conditions used in this study, the uncertainties were:

1.7 percent in $\beta_{0}, 10.5$ percent in $A_{c}, 12.8$ percent in $n_{0}, 0.7$ percent in Re, 1.6 percent in $\mathrm{We}_{L}, 7.4$ percent in $h_{f} / d$, and 22.1 percent in $\mathrm{We}_{f}$.

\section{Results}

In developing the test matrix, reference test conditions were selected such that both reference and scale conditions would fall within the IRT current operating envelope. Due to limited IRT test time available for the scaling evaluation this study is only focused on the strong glaze icing condition regime with SLD reference drop sizes in the range of 70 to $170 \mu \mathrm{m}$. Also, two scale $L W C$ values were chosen for the evaluation of the constant $\mathrm{We}_{L}$ method. Two low stagnation point freezing fraction values of 0.2 and 0.3 were selected to cover a good number of strong glaze ice accretions for evaluation. Most cases were tested with the purpose of acquiring sufficient ice shapes to test repeatability as well.

Figures 2 to 13 and 14 to 25 presented the nondimensional reference and scale 2-D ice sectional cut at mid-span as well as the 3-D ice shape scan image obtained from the constant $W e_{L}$ and constant ( $W e_{f}$ and $h_{f} / d$ ) methods at reference velocities of 100 and $130.3 \mathrm{kt}($ i.e., $150 \mathrm{mph}$ ) for stagnation point freezing fraction $n_{0}$ of 0.2 and 0.3 , respectively. For each figure, the reference ice shape was shown shaded, while a solid line indicated the scale ice shape. The table below each figure gave the test conditions and similarity parameters for each pair of reference and scale tests. The conditions given were the average conditions recorded over the duration of each test, which can sometimes differ slightly from the planned set points. The parameters in the tables were calculated from those average conditions.

\section{Stagnation Point Freezing Fraction of 0.2}

Figures 2 to 5 showed reference and scale ice shape comparisons for the constant $\mathrm{We}_{L}$ and constant (We $\mathrm{We}_{f}$ and $h_{f} / d$ ) methods, respectively. The same reference ice shape was used for both comparisons. The reference model size, velocity and $M V D$ as planned were $72 \mathrm{in.}, 100 \mathrm{kt}$ and $85 \mu \mathrm{m}$. The scale model size was $21 \mathrm{in.} \mathrm{The} \mathrm{coordinates} \mathrm{of} \mathrm{the} \mathrm{ice} \mathrm{shapes} \mathrm{were} \mathrm{all} \mathrm{normalized} \mathrm{by} \mathrm{the} \mathrm{corresponding} \mathrm{model} \mathrm{chord.}$

In Figure 2 the scale and reference values of $\beta_{0} A_{c}$ and $\mathrm{We}_{L}$ were matched within 2 percent and $n_{0}$ was just within 5 percent. The scale ice shape gave a fairly good match of the reference main ice shape, although the feathers just aft of the main shape were slightly larger for the SLD condition and the smaller feather regions were extended further aft for the Appendix $C$ shape. Figure 3 showed the corresponding 3 -D scan images of reference and scale ice shapes. It is noted that although the laser scan images look realistic but the laser scanning still cannot capture all the 3-D features of larger SLD feathers right aft of the main ice shape due to its inherent limitation from the line of sight based technology.

In Figure 4 the scale and reference value of $\beta_{0} A_{c}$ was matched within 4 percent, $n_{0}$ was within 5 percent, $\mathrm{We}_{f}$ and $h_{f} / d$ were just within 6 percent. However due to the relatively higher scale velocity, lower scale $L W C$ and very warm sub-freezing air total temperature (i.e., $t_{\mathrm{tot}, S}=-0.2^{\circ} \mathrm{C}$ ) from matching the film Weber number $\mathrm{We}_{f}$, the film thickness $h_{f} / d$ and $n_{0}$, the resulting scale ice shape featured a narrow thin ice region between the horns along the stagnation line and a feather region being extended further aft which gave a less desirable match of the reference main ice shape. This finding is consistent with early SLD scaling test results reported by Anderson and Tsao (Ref. 5) at the stagnation freezing fraction value of 0.5 that the best match of the SLD shapes occurred when velocities close to the value required to match $\mathrm{We}_{L}$ were selected. Figure 5 showed the corresponding 3-D scan images of reference and scale ice shapes and the narrow strip of thin ice layer along the model leading edge was clearly seen from the scan image. 
Furthermore, Figures 6 to 9 gave another set of SLD scaling results for a higher reference velocity of $130.3 \mathrm{kt}$. The reference $M V D$ was $85 \mu \mathrm{m}$. In Figure 6 , the scale and reference values of $\beta_{0} A_{c}$ and $\mathrm{We}_{L}$ were matched well, and $n_{0}$ was matched within 5 percent. Since a lower scale $L W C$ value was chosen for this constant $\mathrm{We}_{L}$ case, a relatively warm sub-freezing air total temperature (i.e., $t_{\text {tot, } S}=-0.4{ }^{\circ} \mathrm{C}$ ) was required to match the $n_{0}$ for the 21 -in.-chord scale test which still produced a main ice shape in fair agreement with the reference. Although the scale ice shape had a bit wider flat region at the model leading edge, the sizes of large feathers adjacent to the main shape and the smaller feathers further aft were simulated reasonably well. Figure 7 showed the corresponding 3-D scan images of reference and scale ice shapes, and it should be noted that a better match of reference and scale ice shapes can be obtained if a larger scale $L W C$ value was chosen for this case to avoid having an air total temperature so close to the water freezing temperature. This was planned primarily to assess (1) how well the Olsen method (Ref. 2), a method to scale the $L W C$ while maintaining the ice shape similarity, can be applied in the strong glaze icing regime in particular when the air total temperature could be very close to or even higher than the water freezing temperature and (2) how well the 3-D laser scanning system can characterize the resulting glaze ice accretions at conditions where the traditional hand tracing of glaze ice shape onto paper template is considered difficult.

In Figure 8 , the scale and reference values of $\beta_{0} A_{c}$ was matched within 6 percent, $n_{0}$ was within 5 percent, $W e_{f}$ was within 11 percent and $h_{f} / d$ was within 7 percent. Again because of the higher scale velocity (i.e., $V_{S}=296 \mathrm{kt}$ ) coupled with above-freezing air total temperature (i.e., $t_{\text {tot, } S}=1.7^{\circ} \mathrm{C}$ ) from matching the film Weber number $\mathrm{We}_{f}$, the film thickness $\left(h_{f} / d\right)$ and the stagnation point freezing fraction $n_{0}$, the 21-in.-chord scale test produced a main ice shape with a wide thin glaze ice region at the model leading edge. This scale ice shape was completely different from the reference shape, and it was not able to give a good match of the reference shape. Figure 9 showed the corresponding 3-D scan images of reference and scale ice shapes and noticeably this scale ice shape looks rather like a typical runback ice shape observed on a thermally protected wing surface.

Finally, Figures 10 to 13 showed SLD scaling results for a large reference $M V D$ of $170 \mu \mathrm{m}$. The reference velocity was $100 \mathrm{kt}$ as planned. In Figure 10, the scale and reference values of $\beta_{0} A_{c}$ were matched well, $\mathrm{We}_{L}$ was matched with 2 percent, and $n_{0}$ was matched within 5 percent. This time, the 21-in.-chord 60- $\mu \mathrm{m}-M V D$ test produced a main ice shape in very close agreement with the 72 -in.-chord $170-\mu \mathrm{m}-M V D$ shape. The scale ice shape gave an excellent match of the reference main ice shape and feather region, even including smaller feathers further aft on the surface. Figure 11 showed the corresponding 3-D scan images of reference and scale ice shapes.

In Figure 12 the scale and reference value of $\beta_{0} A_{c}, n_{0}$ and $h_{f} / d$ were all matched well, and $\mathrm{We}_{f}$ was within 2 percent. Due to the relatively higher scale velocity, lower scale $L W C$ and fairly warm subfreezing air total temperature (i.e., $t_{\mathrm{tot}, S}=-0.8^{\circ} \mathrm{C}$ ) from matching the film Weber number $\mathrm{We}_{f}$, the film thickness $h_{f} / d$ and $n_{0}$, the 21 -in.-chord scale test produced a main ice shape in fair agreement with the reference. Although the scale ice shape had a bit wider flat region at stagnation point in comparison with the reference shape, the sizes of large feathers adjacent to the main shape and the smaller feathers further aft were still simulated reasonably well. Figure 12 showed the corresponding 3-D scan images of reference and scale ice shapes. 


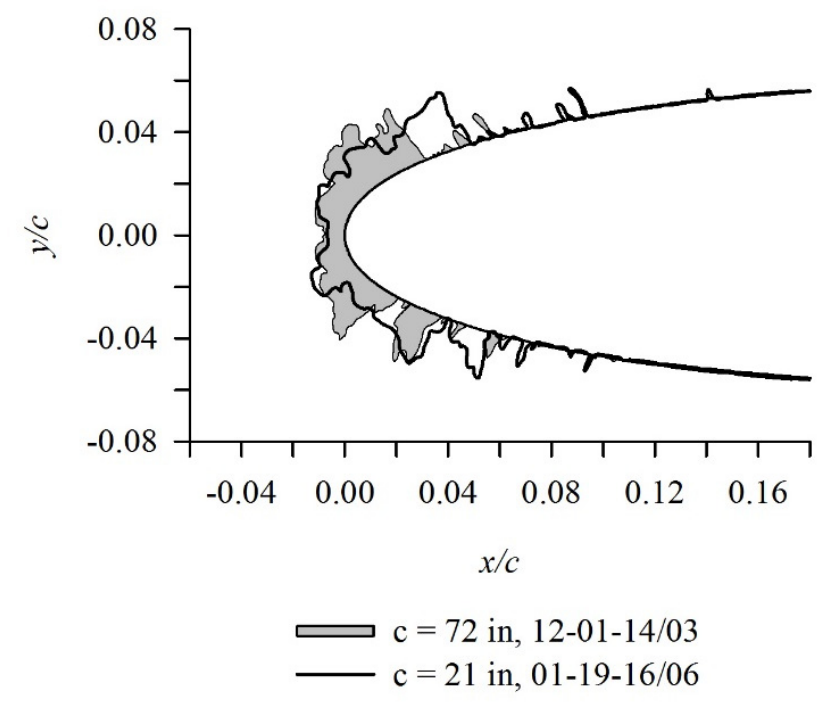

\begin{tabular}{cccccccccccccc}
\multirow{2}{*}{ Date/Run } & $\begin{array}{c}c, \\
\text { in. }\end{array}$ & $\begin{array}{r}t_{\text {tot }}, \\
{ }^{\circ} \mathrm{C}\end{array}$ & $\begin{array}{c}V, \\
\mathrm{kt}\end{array}$ & $\begin{array}{c}M V D, \\
\mu \mathrm{m}\end{array}$ & $\begin{array}{c}L W C, \\
\mathrm{~g} / \mathrm{m}^{3}\end{array}$ & $\begin{array}{c}\tau, \\
\mathrm{min} .\end{array}$ & $\begin{array}{c}\beta_{0}, \\
\text { percent }\end{array}$ & $A_{c}$ & $\beta_{0} A_{c}$ & $n_{0}$ & $\begin{array}{c}\mathrm{We}_{L}, \\
10^{6}\end{array}$ & $\begin{array}{c}\mathrm{We}_{f}, \\
10^{-16}\end{array}$ & $\begin{array}{c}h_{f} / d, \\
10^{-9}\end{array}$ \\
\hline $12-01-14 / 03$ & 72 & -6.0 & 99 & 84 & 1.20 & 23.2 & 82.9 & 1.61 & 1.33 & 0.21 & 2.30 & 2.68 & 0.80 \\
$01-19-16 / 06$ & 21 & -2.7 & 184 & 31 & 1.00 & 4.4 & 83.2 & 1.62 & 1.35 & 0.20 & 2.33 & 7.86 & 1.42
\end{tabular}

Figure 2.-Scaling from 72 to 21 -in.-chord with $\mathrm{We}_{L}$ matched. NACA 0012 airfoils; $n_{0}, 0.2 ; V_{R}, 100 \mathrm{kt} ; M V D_{R}, 85 \mu \mathrm{m}$.
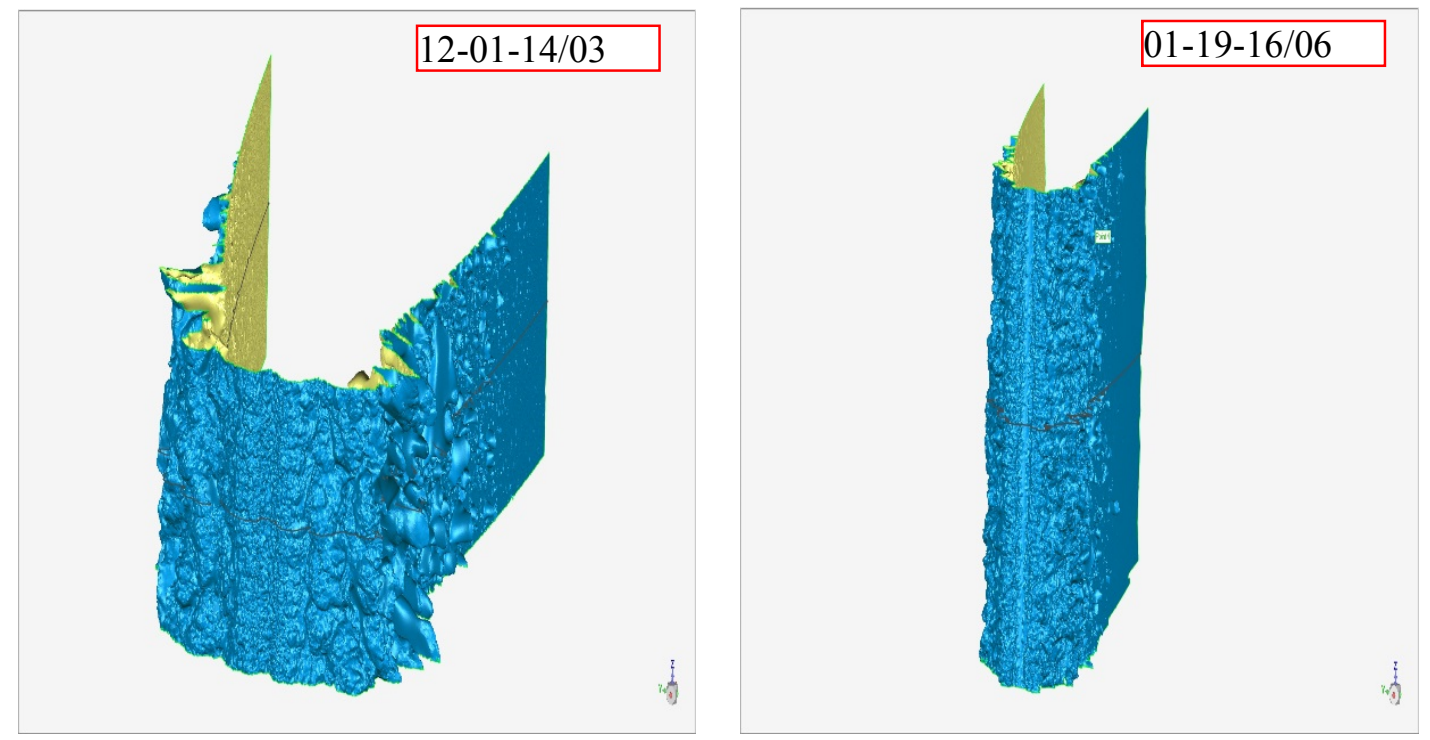

Figure 3.-The corresponding 3-D scan images of the reference and scale ice shapes shown in Figure 2. 


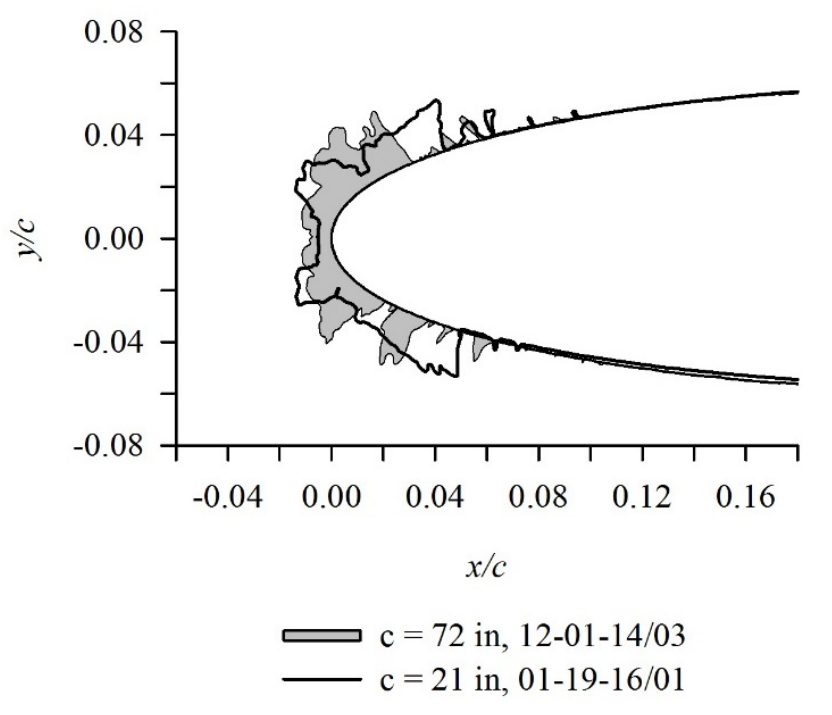

\begin{tabular}{cccccccccccccc} 
Date/Run & $\begin{array}{c}c, \\
\text { in. }\end{array}$ & $\begin{array}{r}t_{\text {tot }}, \\
{ }^{\circ} \mathrm{C}\end{array}$ & $\begin{array}{c}V, \\
\mathrm{kt}\end{array}$ & $\begin{array}{c}M V D, \\
\mu \mathrm{m}\end{array}$ & $\begin{array}{c}L W C, \\
\mathrm{~g} / \mathrm{m}^{3}\end{array}$ & $\begin{array}{c}\tau, \\
\mathrm{min} .\end{array}$ & $\begin{array}{c}\beta_{0}, \\
\%\end{array}$ & $A_{c}$ & $\beta_{0} A_{c}$ & $n_{0}$ & $\begin{array}{c}\mathrm{We}_{L}, \\
10^{6}\end{array}$ & $\begin{array}{c}\mathrm{We} f \\
10^{-16}\end{array}$ & $\begin{array}{c}h_{f} / d, \\
10^{-9}\end{array}$ \\
\hline $12-01-14 / 03$ & 72 & -6.0 & 99 & 84 & 1.20 & 23.2 & 82.9 & 1.61 & 1.33 & 0.21 & 2.30 & 2.68 & 0.80 \\
$01-19-16 / 01$ & 21 & -0.2 & 225 & 28 & 0.54 & 6.3 & 83.2 & 1.66 & 1.38 & 0.20 & 3.55 & 2.81 & 0.83
\end{tabular}

Figure 4.-Scaling from 72 to 21 -in-chord with $W_{f}$ and $\left(h_{f} / d\right)$ matched. NACA 0012 airfoils; $n_{0}, 0.2 ; V_{R}, 100 \mathrm{kt}$; $M V D_{R}, 85 \mu \mathrm{m}$.
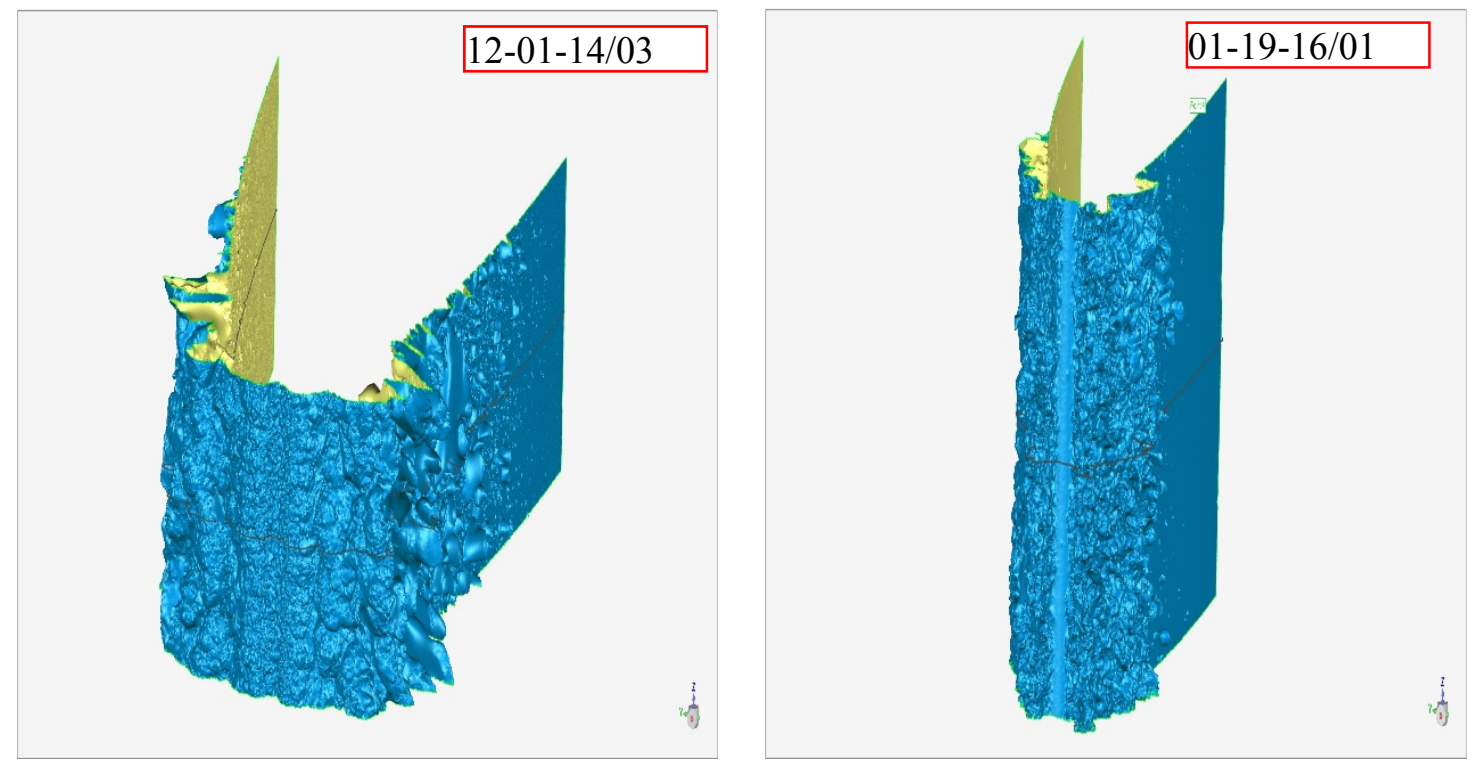

Figure 5.-The corresponding 3-D scan images of the reference and scale ice shapes shown in Figure 4. 


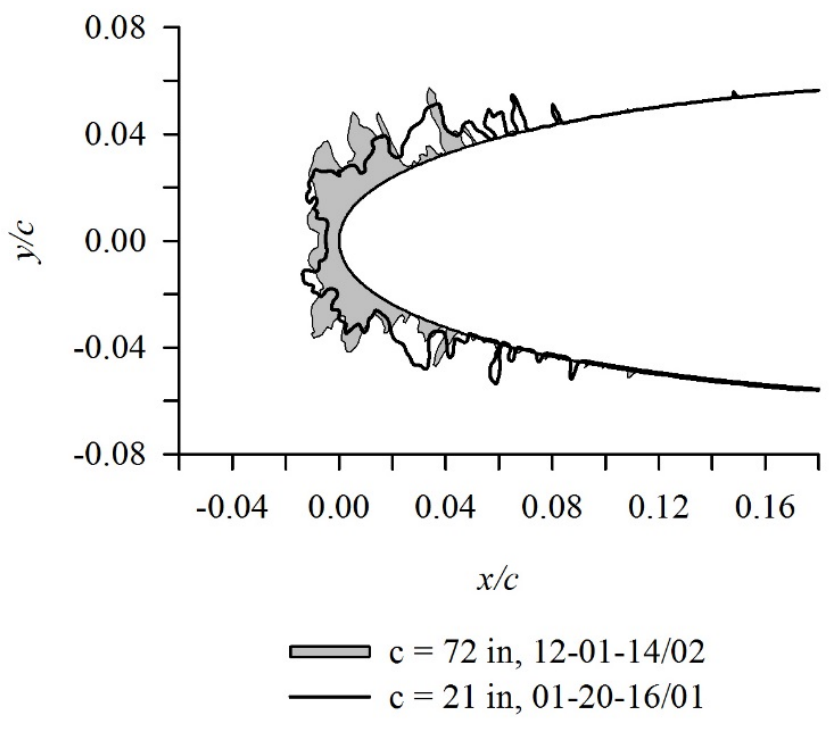

\begin{tabular}{|c|c|c|c|c|c|c|c|c|c|c|c|c|c|}
\hline Date/Run & $\begin{array}{l}c, \\
\text { in. }\end{array}$ & $\begin{array}{l}t_{\text {tot, }} \\
{ }^{\circ} \mathrm{C}\end{array}$ & $\begin{array}{l}V, \\
\mathrm{kt}\end{array}$ & $\begin{array}{c}M V D, \\
\mu \mathrm{m}\end{array}$ & $\begin{array}{l}L W C, \\
\mathrm{~g} / \mathrm{m}^{3}\end{array}$ & $\begin{array}{c}\tau, \\
\min .\end{array}$ & $\begin{array}{c}\beta_{0}, \\
\text { percent }\end{array}$ & $A_{c}$ & $\beta_{0} A_{c}$ & $n_{0}$ & $\begin{array}{c}\mathrm{We}_{L} \\
10^{6}\end{array}$ & $\begin{array}{l}\mathrm{We}_{f}, \\
10^{-16}\end{array}$ & $\begin{array}{l}h_{f} / d, \\
10^{-9}\end{array}$ \\
\hline $12-01-14 / 0$ & 72 & -5.3 & 129 & 85 & 0.95 & 22.1 & 84.7 & 1.57 & 1.33 & 0.21 & 3.91 & 1.52 & 0.51 \\
\hline $01-20-16 / 01$ & 21 & -0.4 & 239 & 30 & 0.60 & 5.5 & 84.8 & 1.59 & 1.34 & 0.20 & 3.93 & 3.06 & 0.81 \\
\hline
\end{tabular}

Figure 6.-Scaling from 72 to 21 -in.-chord with $\mathrm{We}_{L}$ matched. NACA 0012 airfoils; $n_{0}, 0.2 ; V_{R}, 130.3 \mathrm{kt} ; M_{V} D_{R}$, $85 \mu \mathrm{m}$.
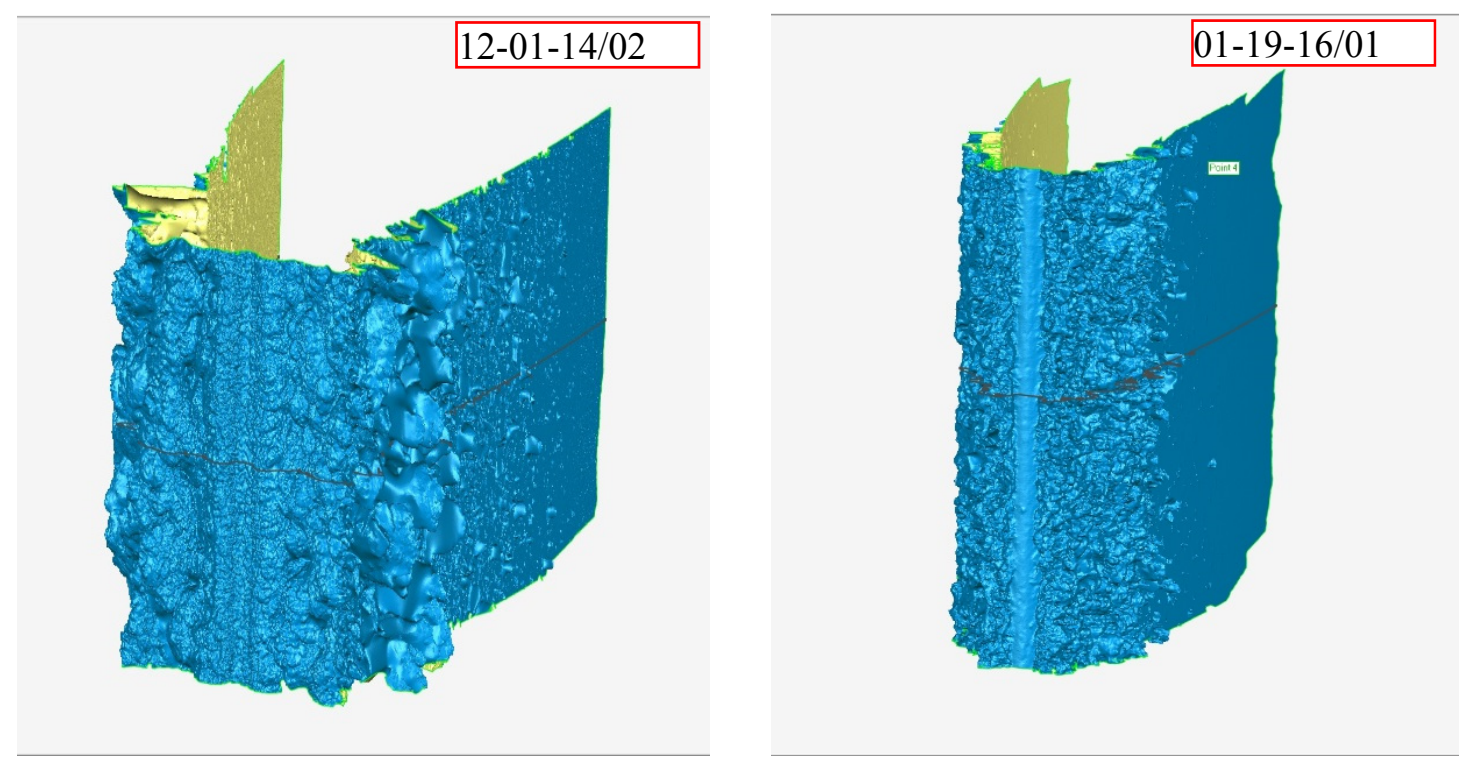

Figure 7.-The corresponding 3-D scan images of the reference and scale ice shapes shown in Figure 6. 


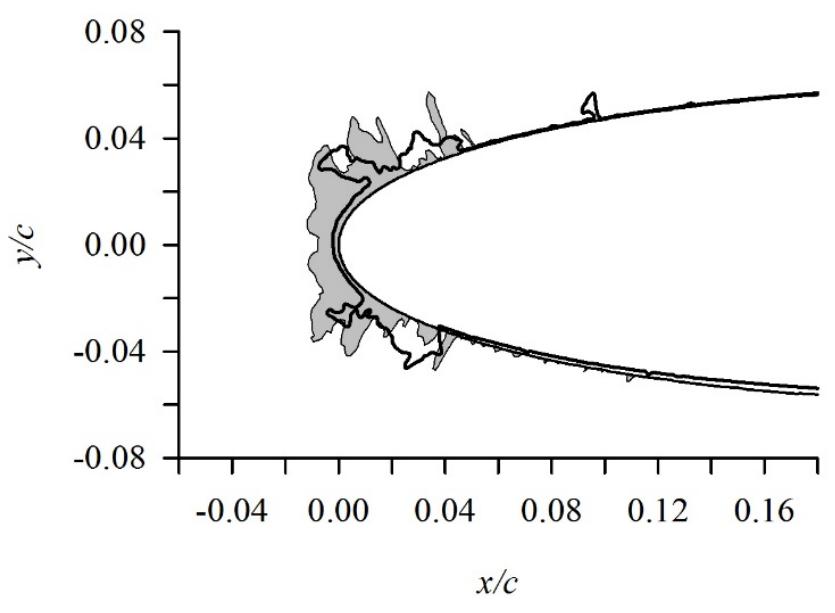

\begin{tabular}{|c|c|c|c|c|c|c|c|c|c|c|c|c|c|}
\hline \multirow[b]{2}{*}{ Date/Run } & \multirow[b]{2}{*}{$\begin{array}{l}c, \\
\text { in. }\end{array}$} & \multirow[b]{2}{*}{$\begin{array}{l}t_{\mathrm{tot}} \\
{ }^{\circ} \mathrm{C}\end{array}$} & \multirow[b]{2}{*}{$\begin{array}{l}V, \\
\mathrm{kt}\end{array}$} & \multirow[b]{2}{*}{$\begin{array}{c}M V D, \\
\mu \mathrm{m}\end{array}$} & \multicolumn{4}{|c|}{$\begin{array}{r}\mathrm{c}=72 \mathrm{in}, 12-01-14 / 02 \\
\mathrm{c}=21 \mathrm{in}, 01-26-16 / 01\end{array}$} & \multirow[b]{2}{*}{$\beta_{0} A_{c}$} & \multirow[b]{2}{*}{$n_{0}$} & \multirow[b]{2}{*}{$\begin{array}{c}\mathrm{We}_{L}, \\
10^{6}\end{array}$} & \multirow[b]{2}{*}{$\begin{array}{c}\mathrm{We}, \\
10^{-16}\end{array}$} & \multirow[b]{2}{*}{$\begin{array}{l}h_{f} / d, \\
10^{-9}\end{array}$} \\
\hline & & & & & $\begin{array}{l}L W C, \\
\mathrm{~g} / \mathrm{m}^{3}\end{array}$ & $\begin{array}{c}\tau \\
\min \end{array}$ & $\begin{array}{c}\beta_{0}, \\
\text { percent }\end{array}$ & $A_{c}$ & & & & & \\
\hline $12-01-14 / 02$ & 72 & -5.3 & 129 & 85 & 0.95 & 22.1 & 84.7 & 1.57 & 1.33 & 0.21 & 3.91 & 1.52 & 0.51 \\
\hline $01-26-16 / 01$ & 21 & 1.7 & 296 & 28 & 0.42 & 6.7 & 84.9 & 1.67 & 1.41 & 0.20 & 6.00 & 1.71 & 0.55 \\
\hline
\end{tabular}

Figure 8.-Scaling from 72 to 21 -in.-chord with $W_{f}$ and $\left(h_{f} / d\right)$ matched. NACA 0012 airfoils; $n_{0}, 0.2 ; V_{R}, 130.3 \mathrm{kt}$; $M V D_{R}, 85 \mu \mathrm{m}$.
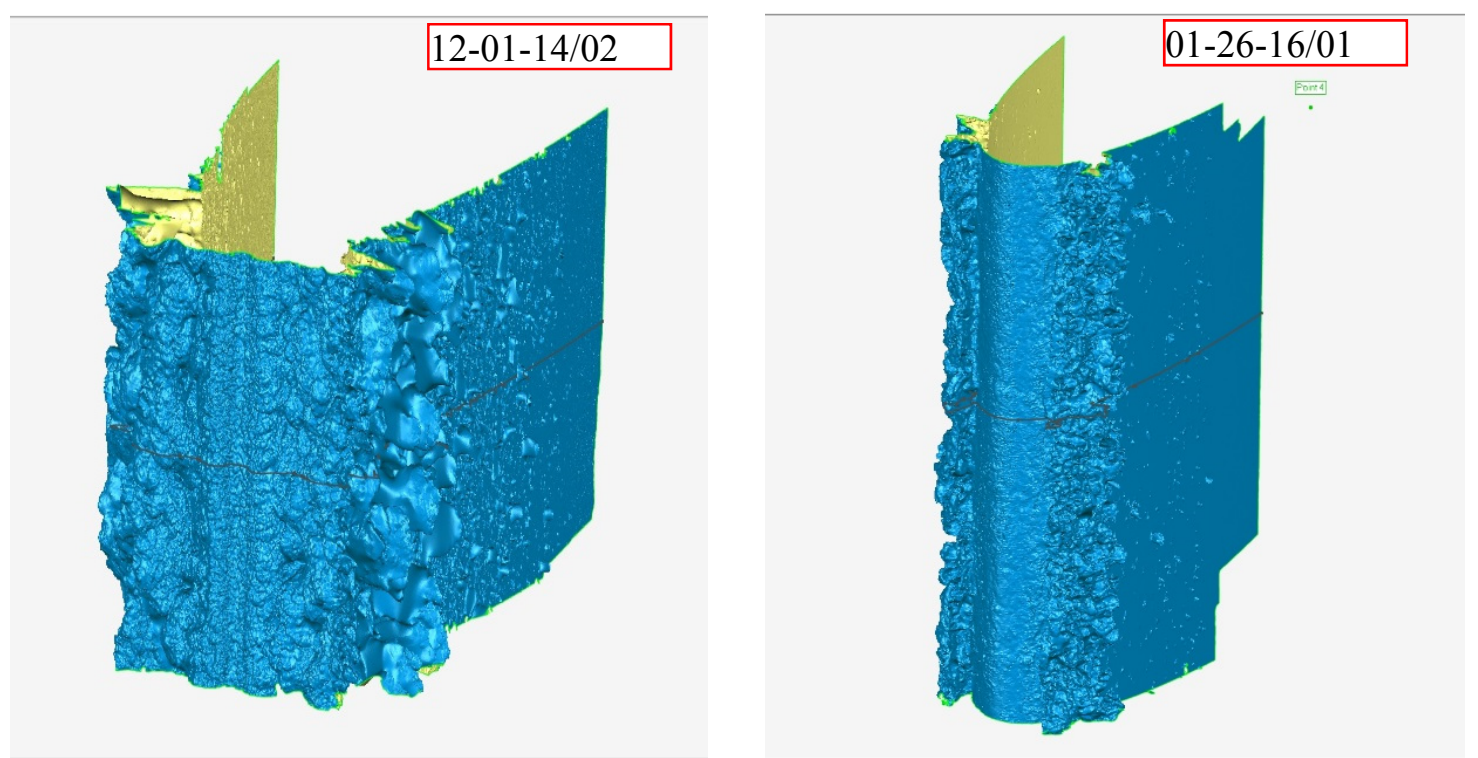

Figure 9.-The corresponding 3-D scan images of the reference and scale ice shapes shown in Figure 8. 


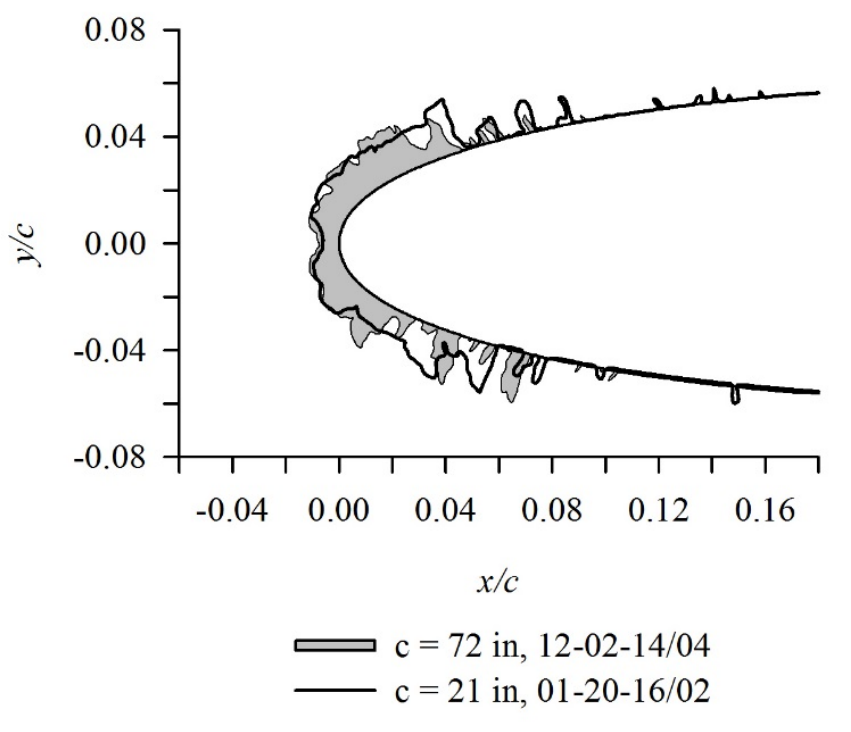

\begin{tabular}{cccccccccccccc} 
Date/Run & $\begin{array}{c}c, \\
\text { in. }\end{array}$ & $\begin{array}{c}t_{\text {tot, }}, \\
{ }^{\circ} \mathrm{C}\end{array}$ & $\begin{array}{c}V, \\
\mathrm{kt}\end{array}$ & $\begin{array}{c}M V D, \\
\mu \mathrm{m}\end{array}$ & $\begin{array}{c}L W C, \\
\mathrm{~g} / \mathrm{m}^{3}\end{array}$ & $\begin{array}{c}\tau, \\
\min \end{array}$ & $\begin{array}{c}\beta_{0}, \\
\text { percent }\end{array}$ & $A_{c}$ & $\beta_{0} A_{c}$ & $\begin{array}{c}n_{0} \\
\mathrm{We}_{L},\end{array}$ & $\begin{array}{c}\mathrm{We}_{f}, \\
10^{6}\end{array}$ & $\begin{array}{c}h_{f} / d, \\
10^{-16} \\
10^{-9}\end{array}$ \\
\hline $12-02-14 / 04$ & 72 & -6.9 & 99 & 171 & 1.35 & 18.6 & 92.3 & 1.45 & 1.34 & 0.20 & 2.30 & 1.10 & 0.60 \\
$01-20-16 / 02$ & 21 & -1.2 & 185 & 59 & 0.50 & 7.9 & 92.2 & 1.46 & 1.35 & 0.21 & 2.34 & 1.02 & 0.72
\end{tabular}

Figure 10.-Scaling from 72 to 21 -in.-chord with We $e_{L}$ matched. NACA 0012 airfoils; $n_{0}, 0.2 ; V_{R}, 100 \mathrm{kt} ; M V D_{R}, 170 \mu \mathrm{m}$.
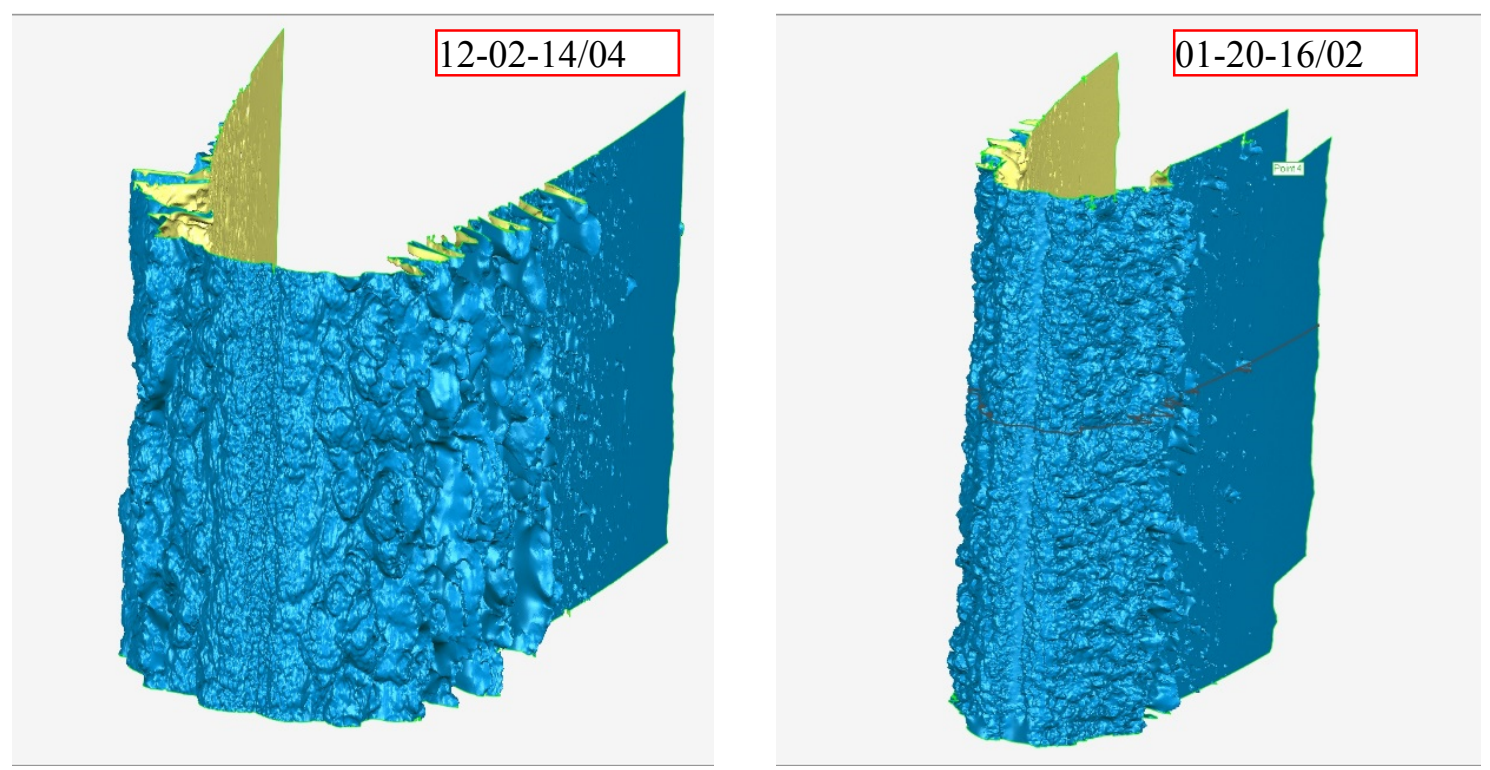

Figure 11.-The corresponding 3-D scan images of the reference and scale ice shapes shown in Figure 10. 


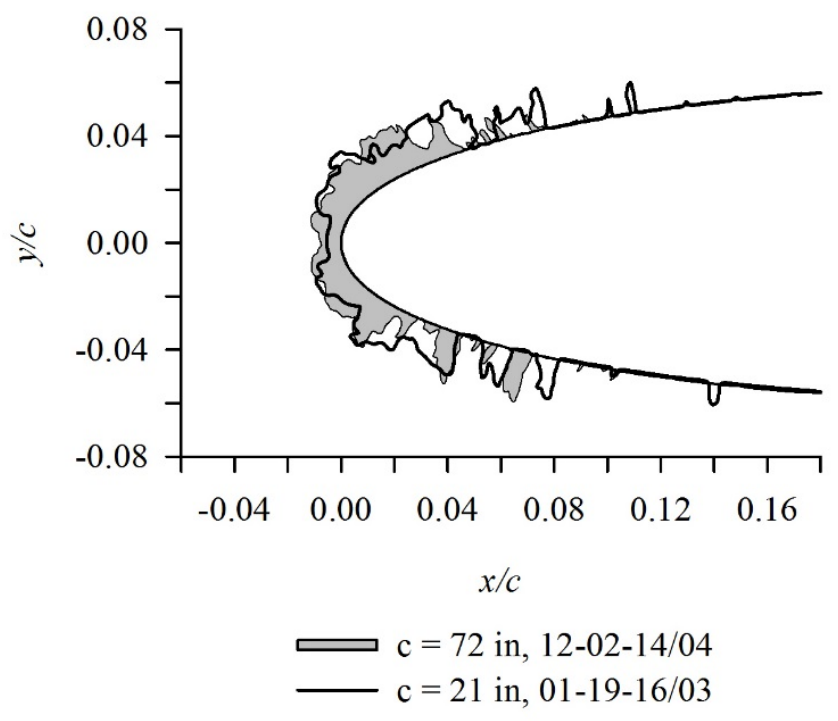

\begin{tabular}{|c|c|c|c|c|c|c|c|c|c|c|c|c|c|}
\hline Date/Run & $\begin{array}{l}c, \\
\text { in. }\end{array}$ & $\begin{array}{l}t_{\mathrm{tot}}, \\
{ }^{\circ} \mathrm{C}\end{array}$ & $\begin{array}{l}V, \\
\mathrm{kt}\end{array}$ & $\begin{array}{c}M V D, \\
\mu \mathrm{m}\end{array}$ & $\begin{array}{l}L W C, \\
\mathrm{~g} / \mathrm{m}^{3}\end{array}$ & $\begin{array}{c}\tau, \\
\min \end{array}$ & $\begin{array}{c}\beta_{0}, \\
\text { percent }\end{array}$ & $A_{c}$ & $\beta_{0} A_{c}$ & no & $\begin{array}{c}\mathrm{We}_{L}, \\
10^{6}\end{array}$ & $\begin{array}{l}\mathrm{We}_{f}, \\
10^{-16}\end{array}$ & $\begin{array}{l}h_{f} / d, \\
10^{-9}\end{array}$ \\
\hline $12-02-14 / 04$ & 72 & -6.9 & 99 & 171 & 1.35 & 18.6 & 92.3 & 1.45 & 1.34 & 0.20 & 2.30 & 1.10 & 0.60 \\
\hline $01-19-16 / 03$ & 21 & -0.8 & 226 & 58 & 0.56 & 5.7 & 92.6 & 1.44 & 1.33 & 0.20 & 3.52 & 1.08 & 0.60 \\
\hline
\end{tabular}

Figure 12.-Scaling from 72 to 21 -in.-chord with $W_{f}$ and $\left(h_{f} / d\right)$ matched. NACA 0012 airfoils; $n_{0}, 0.2 ; V_{R}, 100 \mathrm{kt}$; $M V D_{R}, 170 \mu \mathrm{m}$.
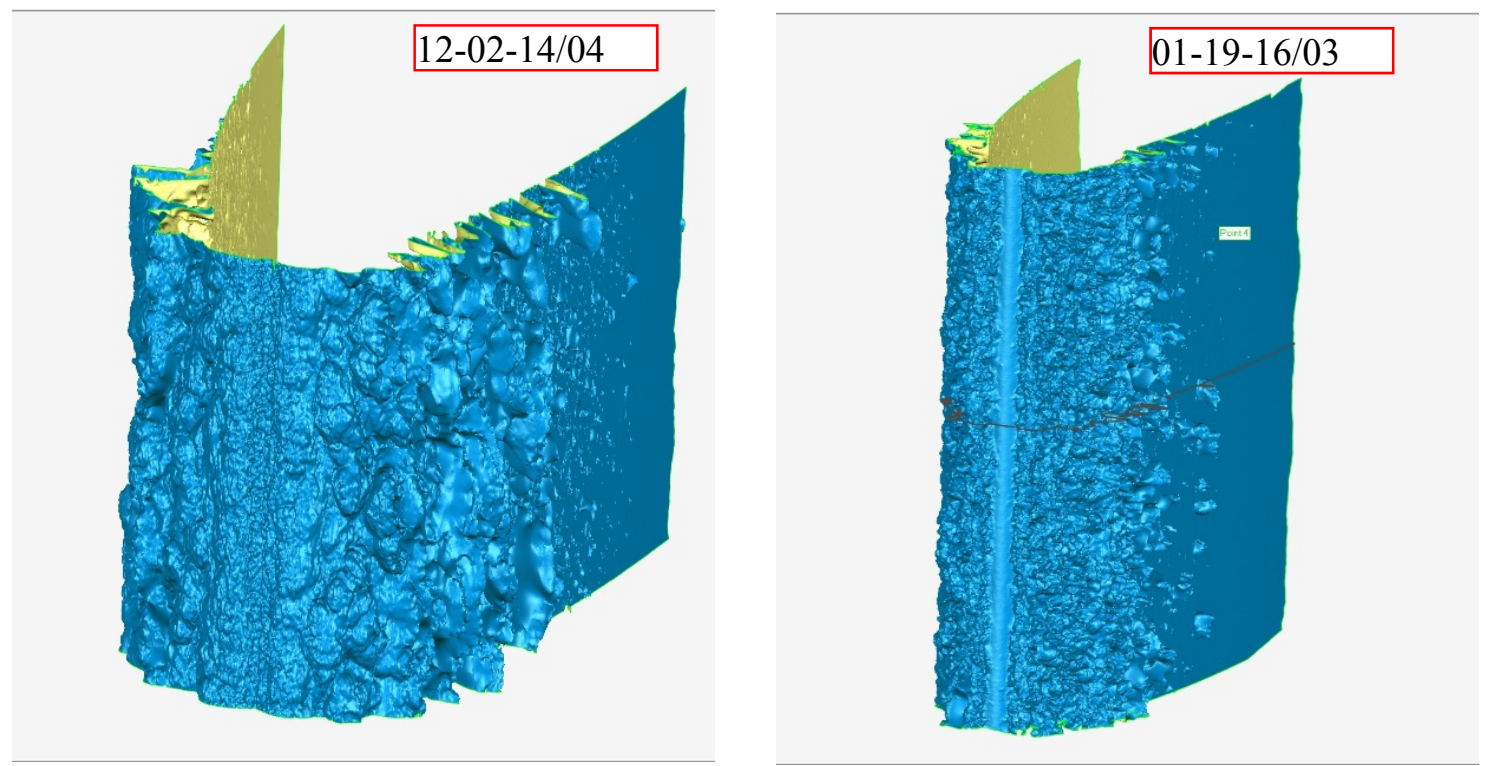

Figure 13.-The corresponding 3-D scan images of the reference and scale ice shapes shown in Figure 12. 


\section{Stagnation Point Freezing Fraction of 0.3}

Figures 14 to 17 each compare reference and scale ice shapes with the 72-in. reference conditions scaled to $21 \mathrm{in}$. The same reference ice shape was used for both comparisons. The reference velocity and MVD were $100 \mathrm{kt}$ and $85 \mu \mathrm{m}$. In Figure 14 the scale velocity was calculated from Equation (13), whereas for Figure 16 that was obtained from Equation (17).

In Figure 14 the scale and reference values of $\beta_{0} A_{c}$ and $\mathrm{We}_{L}$ were matched well, and $n_{0}$ was matched within 3 percent, and the size and shape of the reference ice were well simulated by the scale test in the leading-edge region. However, some scale ice feathers were larger than recorded in the reference test. Further study to isolate these large-feather conditions is needed to improve scaling performance. Figure 15 showed the corresponding 3-D scan images of reference and scale ice shapes.

In Figure 16 the scale and reference values of $\beta_{0} A_{c}$ was matched within 3 percent, $n_{0}$ was within 3 percent, $W e_{f}$ agreed within 5 percent and $h_{f} / d$ was also within 5 percent. Possibly due to the relatively higher scale velocity, the scale ice shape did not give a good match of the reference shape. In particular, the scale ice shape had a larger flat region at the leading edge between the two bigger horns that were clearly being pushed back further aft now though the horn angle still remained similar. Figure 17 showed the corresponding 3-D scan images of reference and scale ice shapes.

For a higher reference velocity of $130.3 \mathrm{kt}$, similar ice shape comparisons were made with the 72 -in. reference conditions scaled to 21 in., and the results were shown in Figures 18 to 21 . The reference MVD was $85 \mu \mathrm{m}$ and the scale MVD was about $30 \mu \mathrm{m}$. In Figure 18, the scale and reference values of $\beta_{0} A_{c}$ and $\mathrm{We}_{L}$ were matched well. Reference and scale $n_{0}$ was matched within about 6 percent, the scale ice shape was able to simulate the reference main ice shape and feather region well. However the scale ice horn was bigger in size and had a slightly larger angle. Figure 19 showed the corresponding 3-D scan images of reference and scale ice shapes.

In Figure 20, the scale and reference values of $\beta_{0} A_{c}$ was matched within 5 percent, $n_{0}$ was within 3 percent, $\mathrm{We}_{f}$ was matched within about 12 percent, and $h_{f} / d$ agreed within 9 percent. Similarly because of the higher scale velocity (i.e., $V_{S}=296 \mathrm{kt}$ ) coupled with slightly above-freezing air total temperature (i.e. $t_{\text {tot } S}=0.1^{\circ} \mathrm{C}$ ) from matching the film Weber number $\mathrm{We}_{f}$, the film thickness $\left(h_{f} / d\right)$ and the stagnation point freezing fraction $n_{0}$, the 21 -in.-chord scale test produced a main ice shape with a wide glaze ice region at the model leading edge. This scale ice shape was different from the reference shape, and it was not able to give a good simulation of the reference shape. Figure 21 showed the corresponding 3-D scan images of reference and scale ice shapes.

Lastly, Figures 22 to 25 showed SLD scaling results for a large reference $M V D$ of $170 \mu \mathrm{m}$. The reference velocity was $100 \mathrm{kt}$. In Figure 22, the scale and reference values of $\beta_{0} A_{c}$ was matched within 7 percent, $\mathrm{We}_{L}$ was matched with 2 percent, and $n_{0}$ was matched within 9 percent. This time, the 21-in.-chord 60- $\mu \mathrm{m}-M V D$ test produced a main ice shape in very close agreement with the 72 -in.-chord $170-\mu \mathrm{m}-M V D$ shape. The scale ice shape gave an excellent match of the reference main ice shape and feather region, even including smaller feathers further aft on the surface. Figure 23 showed the corresponding 3-D scan images of reference and scale ice shapes.

In Figure 24 the scale and reference value of $\beta_{0} A_{c}, \mathrm{We}_{f}$ and $h_{f} / d$ were all matched within 2 percent, and $n_{0}$ was well. The 21 -in.-chord scale test produced a main ice shape in fairly good agreement with the reference. Although the scale ice shape still had a bit wider flat region at stagnation point in comparison with the reference shape and the scale horn was a bit longer, the sizes of large feathers adjacent to the main shape and the smaller feathers further aft were still simulated reasonably well. Figure 25 showed the corresponding 3-D scan images of reference and scale ice shapes.

Given the repeatability variations encountered in the IRT for SLD conditions, it can be concluded that for SLD icing clouds in conditions where the droplet impact could interact strongly with the surface shear-driven film flow when the freezing process is slow the constant $\mathrm{We}_{L}$ method is a better choice of similarity parameter for determining scale velocity than the constant $\left(\mathrm{We}_{f}\right.$ and $h / d$ ) method at low stagnation point freezing fractions of 0.2 and 0.3 . As for the scale liquid water content it is still 
recommended to use the Olsen method to find an appropriately calibrated $L W C$ value available in the icing test facility that will give an air total temperature not warmer than $-2{ }^{\circ} \mathrm{C}$ for any given glaze icing condition.

Additional tests at these lower freezing fractions are needed to better assess the constant $\mathrm{We}_{L}$ method. The current assessment suggests that the constant $\mathrm{We}_{L}$ methods can produce acceptable ice shape scaling simulation for the stagnation point freezing fraction $n_{0}$ as low as 0.2 . If scale simulations are needed at such low freezing fractions, it is recommended that, due to the variability of shapes, tests be repeated with more than one test entry.
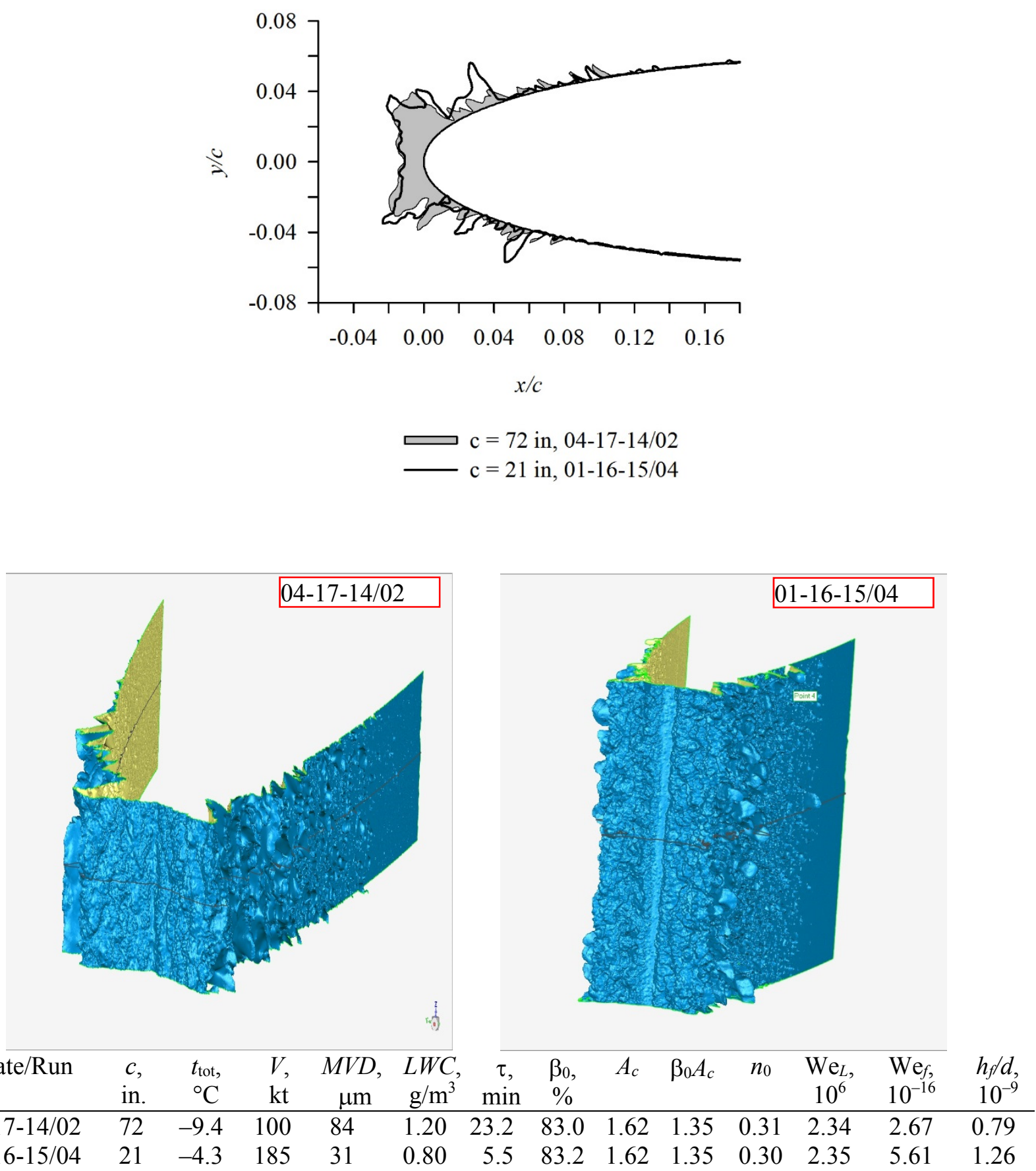

Figure 14.-Scaling from 72 to 21 -in.-chord with $W_{L}$ matched. NACA 0012 airfoils; $n_{0}, 0.3 ; V_{R}, 100 \mathrm{kt} ; M V D_{R}, 85 \mu \mathrm{m}$. 

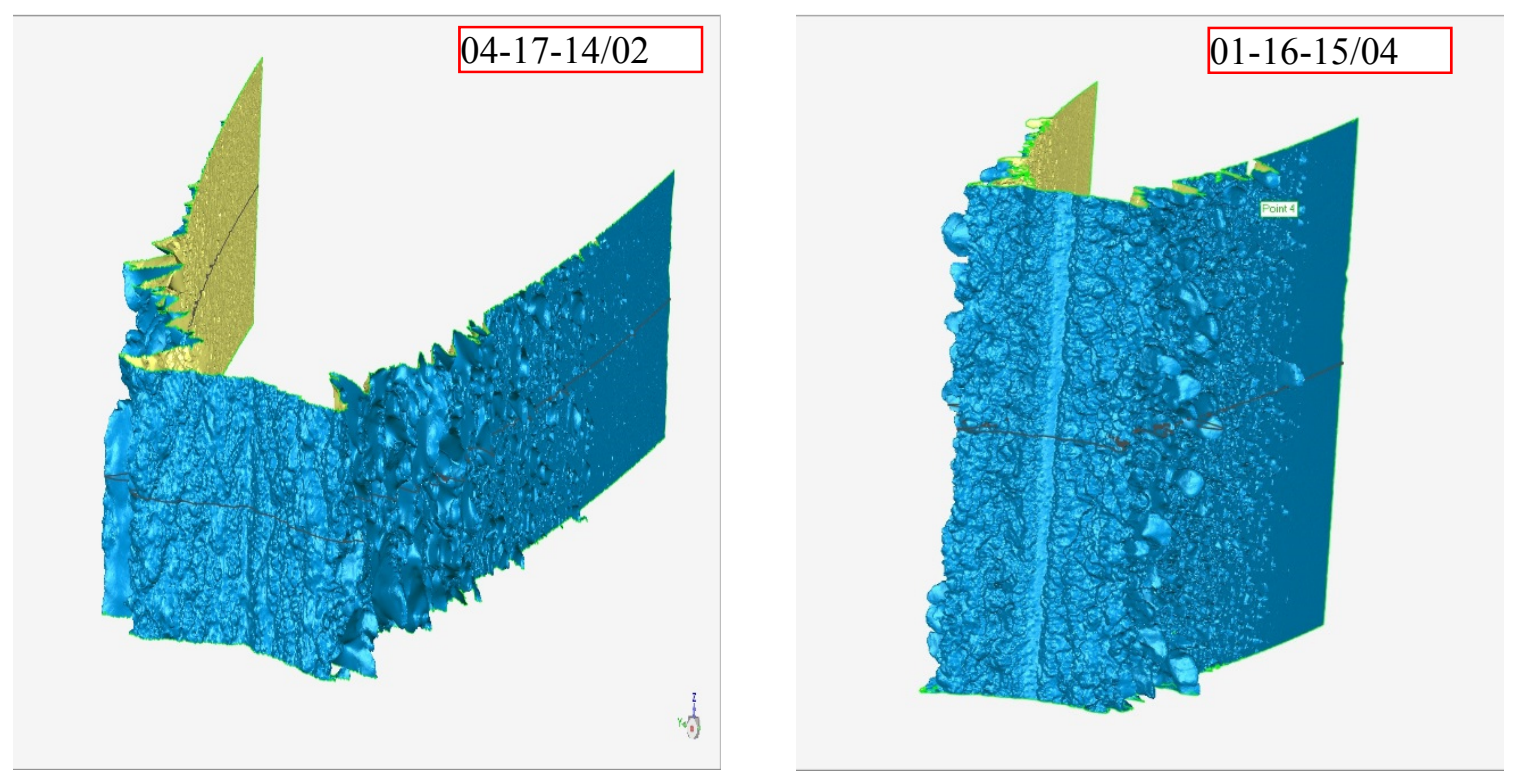

Figure 15.-The corresponding 3-D scan images of the reference and scale ice shapes shown in Figure 14.

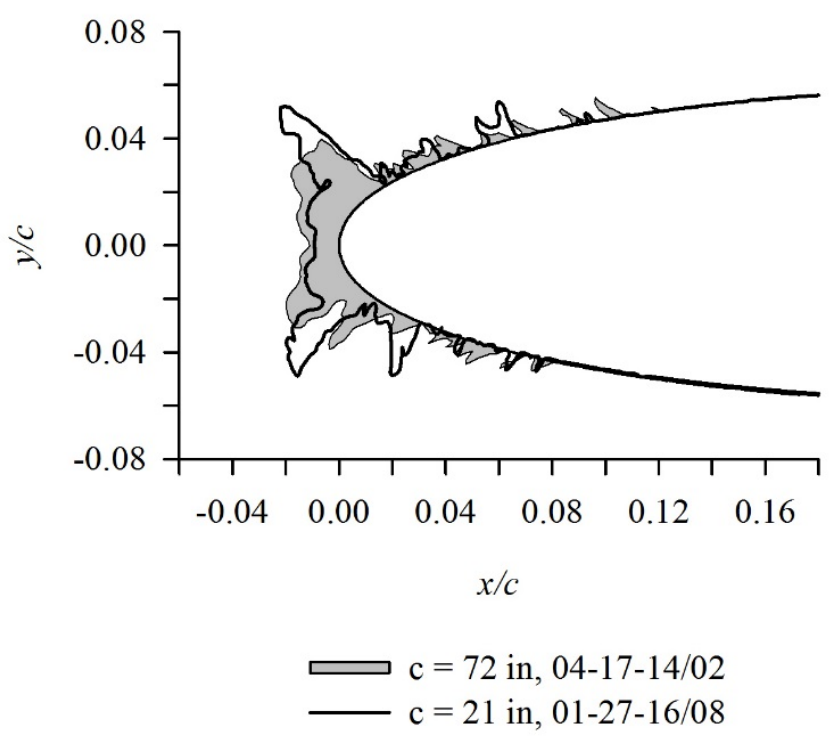

\begin{tabular}{cccccccccccccc} 
Date/Run & $\begin{array}{c}c, \\
\text { in. }\end{array}$ & $\begin{array}{r}t_{\text {tot, }}{ }^{\circ} \mathrm{C} \\
\text { (nt }\end{array}$ & $\begin{array}{c}V, \\
\mathrm{kt}\end{array}$ & $\begin{array}{c}M V D, \\
\mu \mathrm{m}\end{array}$ & $\begin{array}{c}L W C, \\
\mathrm{~g} / \mathrm{m}^{3}\end{array}$ & $\begin{array}{c}\tau, \\
\text { min. }\end{array}$ & $\begin{array}{c}\beta_{0}, \\
\text { percent }\end{array}$ & $A_{c}$ & $\beta_{0} A_{c}$ & $n_{0}$ & $\begin{array}{c}\mathrm{We}_{L}, \\
10^{6}\end{array}$ & $\begin{array}{c}\mathrm{We}_{f}, \\
10^{-16}\end{array}$ & $\begin{array}{c}h_{f} / d, \\
10^{-9}\end{array}$ \\
\hline $04-17-14 / 02$ & 72 & -9.4 & 100 & 84 & 1.20 & 23.2 & 83.0 & 1. & 1.35 & 0.31 & 2.34 & 2.67 & 0.79 \\
$01-27-16 / 08$ & 21 & -2.0 & 227 & 28 & 0.52 & 7.1 & 83.3 & 1. & 1.39 & 0.30 & 3.52 & 2.82 & 0.83
\end{tabular}

Figure 16.-Scaling from 72 to 21 -in.-chord with $W_{f}$ and $\left(h_{f} / d\right)$ matched. NACA 0012 airfoils; $n_{0}, 0.3 ; V_{R}, 100 \mathrm{kt}$; $M V D_{R}, 85 \mu \mathrm{m}$. 

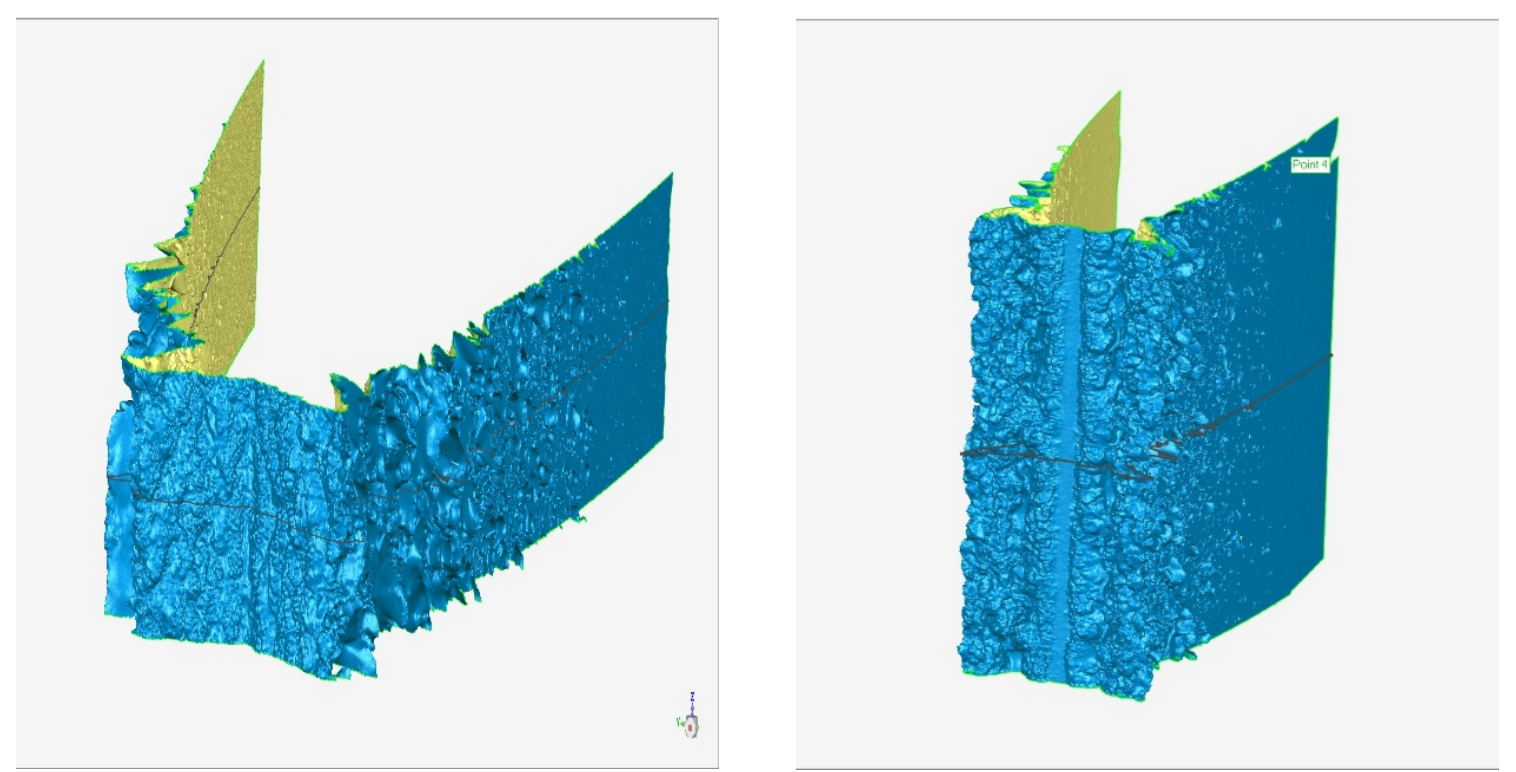

Figure 17.-The corresponding 3-D scan images of the reference and scale ice shapes shown in Figure 16.

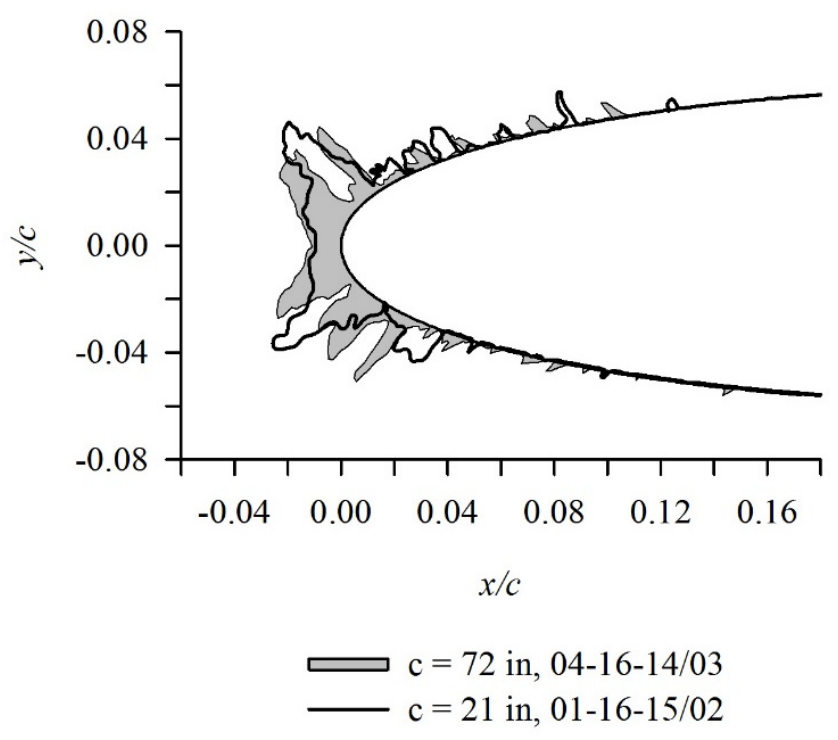

\begin{tabular}{ccrrrrrrrrrrrr} 
Date/Run & $\begin{array}{c}c, \\
\text { in. }\end{array}$ & $\begin{array}{r}t_{\text {tot }}, \\
{ }^{\circ} \mathrm{C}\end{array}$ & $\begin{array}{r}V, \\
\mathrm{kt}\end{array}$ & $\begin{array}{c}M V D, \\
\mu \mathrm{m}\end{array}$ & $\begin{array}{c}L W C, \\
\mathrm{~g} / \mathrm{m}^{3}\end{array}$ & $\begin{array}{r}\tau, \\
\mathrm{min}\end{array}$ & $\begin{array}{c}\beta_{0}, \\
\text { percent }\end{array}$ & $A_{c}$ & $\beta_{0} A_{c}$ & $n_{0}$ & $\begin{array}{c}\mathrm{We}_{L}, \\
10^{6}\end{array}$ & $\begin{array}{c}\mathrm{We}_{f}, \\
10^{-16}\end{array}$ & $\begin{array}{c}h_{f} / d, \\
10^{-9}\end{array}$ \\
\hline $04-16-14 / 03$ & 72 & -8.5 & 130 & 85 & 0.95 & 22.1 & 84.7 & 1.59 & 1.34 & 0.30 & 3.97 & 1.52 & 0.50 \\
$01-16-15 / 02$ & 21 & -2.7 & 241 & 30 & 0.60 & 5.5 & 84.8 & 1.59 & 1.34 & 0.32 & 3.97 & 3.04 & 0.80
\end{tabular}

Figure 18.-Scaling from 72 to 21 -in.-chord with We $L$ matched. NACA 0012 airfoils; $n_{0}, 0.3 ; V_{R}, 130.3 \mathrm{kt} ; M V D_{R}, 85 \mu \mathrm{m}$. 

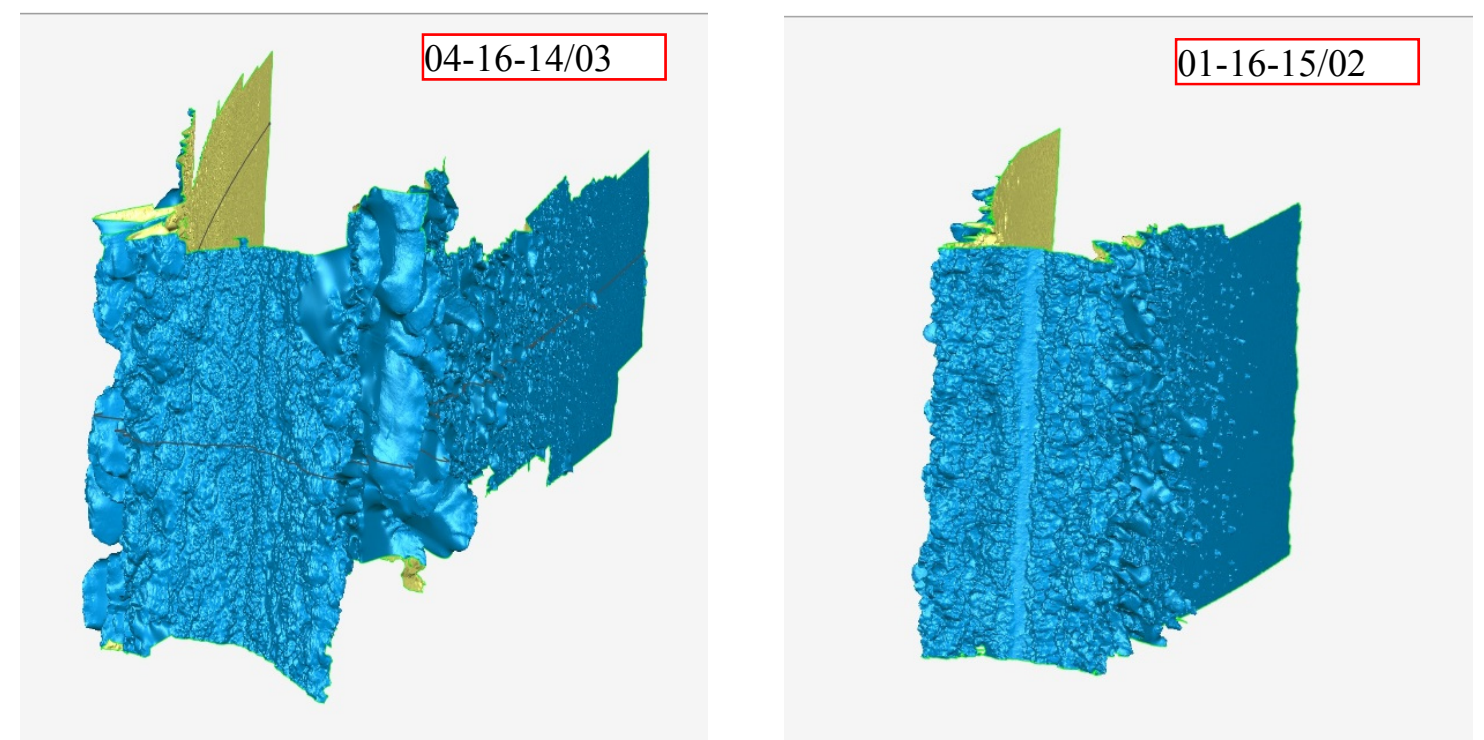

Figure 19.-The corresponding 3-D scan images of the reference and scale ice shapes shown in Figure 18.

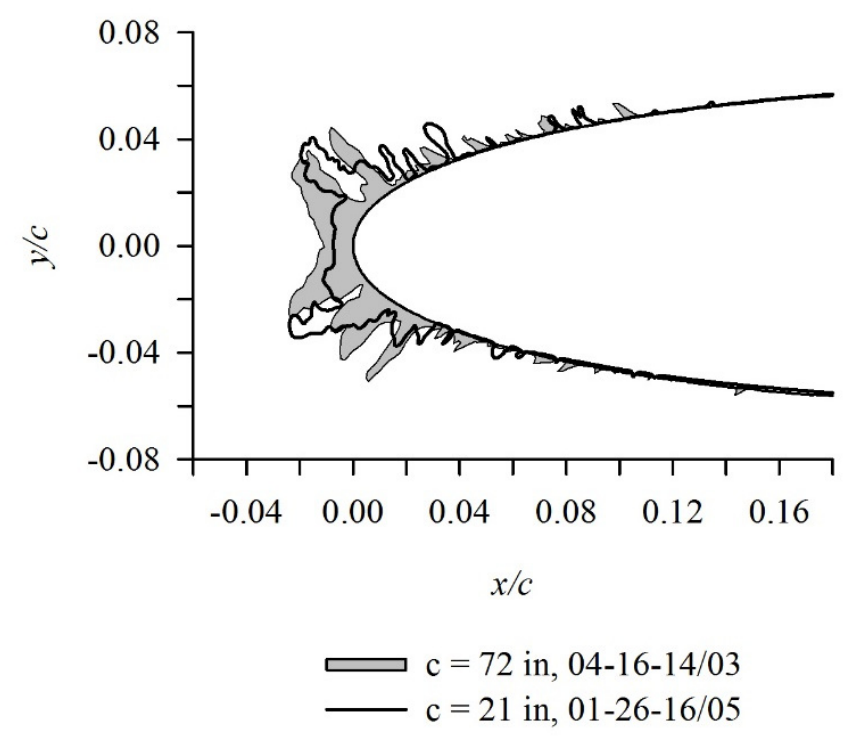

\begin{tabular}{|c|c|c|c|c|c|c|c|c|c|c|c|c|c|}
\hline Date/Run & $\begin{array}{l}c, \\
\text { in. }\end{array}$ & $\begin{array}{l}t_{\mathrm{tot}}, \\
{ }^{\circ} \mathrm{C}\end{array}$ & $\begin{array}{l}V, \\
\mathrm{kt}\end{array}$ & $\begin{array}{c}M V D, \\
\mu \mathrm{m}\end{array}$ & $\begin{array}{l}L W C, \\
\mathrm{~g} / \mathrm{m}^{3}\end{array}$ & $\begin{array}{c}\tau, \\
\min \end{array}$ & $\begin{array}{c}\beta_{0}, \\
\text { percent }\end{array}$ & $A_{c}$ & $\beta_{0} A_{c}$ & $n_{0}$ & $\begin{array}{c}\mathrm{We}_{L} \\
10^{6}\end{array}$ & $\begin{array}{c}\mathrm{We}_{f} \\
10^{-16}\end{array}$ & $\begin{array}{l}h_{f} / d, \\
10^{-9}\end{array}$ \\
\hline$-16-14 / 03$ & 72 & -8.5 & 130 & 85 & 0.95 & 22.1 & 84.7 & 1.59 & 1.34 & 0.30 & 3.97 & 1.52 & 0.50 \\
\hline /05 & 21 & 0.1 & 294 & 28 & 0.42 & 6.7 & 1.8 & 1.66 & 1.41 & 0.29 & 5.92 & 1.73 & 0. \\
\hline
\end{tabular}

Figure 20.-Scaling from 72 to 21 -in.-chord with $W_{f}$ and $\left(h_{f} / d\right)$ matched. NACA 0012 airfoils; $n_{0}, 0.3 ; V_{R}, 130.3 \mathrm{kt}$; $M V D_{R}, 85 \mu \mathrm{m}$. 

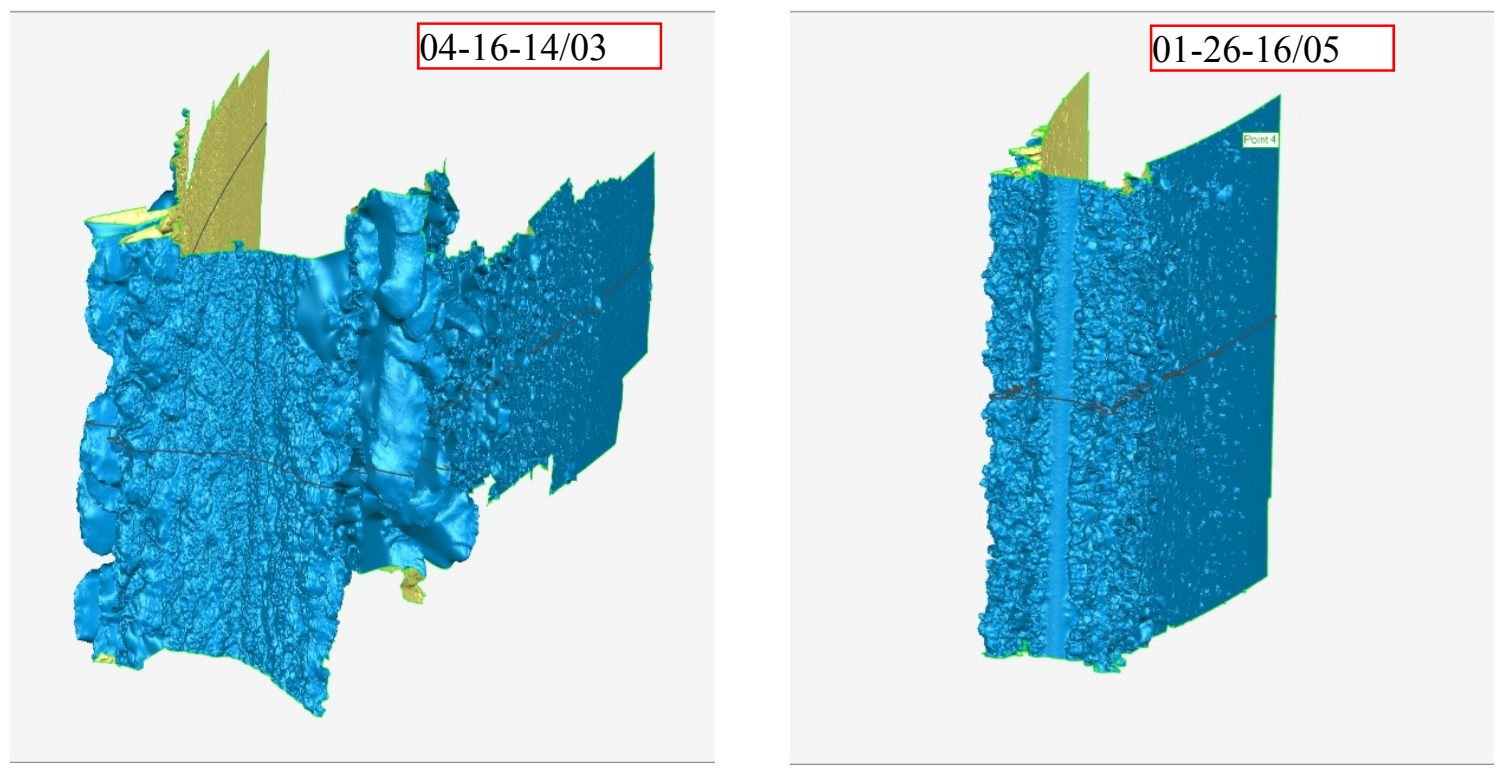

Figure 21.-The corresponding 3-D scan images of the reference and scale ice shapes shown in Figure 20.

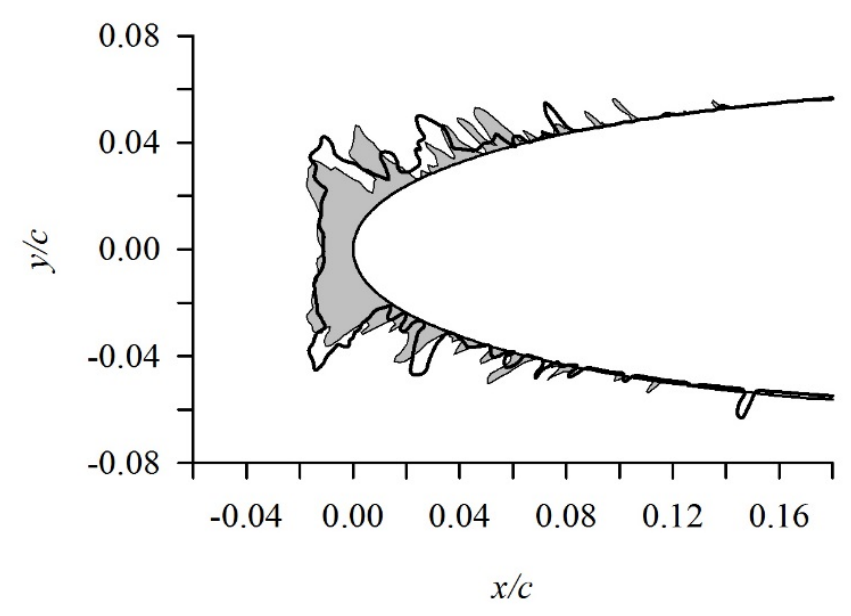

$$
\begin{aligned}
& \mathrm{c}=72 \text { in, } 10-20-14 / 02 \\
& \mathrm{c}=21 \text { in, } 01-16-15 / 03
\end{aligned}
$$

\begin{tabular}{cccccccccccccc} 
Date/Run & $\begin{array}{c}c, \\
\text { in. }\end{array}$ & $\begin{array}{c}t_{\text {tot, }}{ }^{\circ} \mathrm{C} \\
\end{array}$ & $\begin{array}{c}V, \\
\mathrm{kt}\end{array}$ & $\begin{array}{c}M V D, \\
\mu \mathrm{m}\end{array}$ & $\begin{array}{c}L W C, \\
\mathrm{~g} / \mathrm{m}^{3}\end{array}$ & $\begin{array}{c}\tau, \\
\text { min. }\end{array}$ & $\begin{array}{c}\beta_{0}, \\
\text { percent }\end{array}$ & $A_{c}$ & $\beta_{0} A_{c}$ & $n_{0}$ & $\begin{array}{c}\mathrm{We}_{L}, \\
10^{6}\end{array}$ & $\begin{array}{c}\mathrm{We}_{f}, \\
10^{-16}\end{array}$ & $\begin{array}{c}h_{f} / d, \\
10^{-9}\end{array}$ \\
\hline $10-20-14 / 02$ & 72 & -10.8 & 99 & 171 & 1.35 & 18.6 & 92.4 & 1.45 & 1.34 & 0.30 & 2.30 & 1.10 & 0.59 \\
$01-16-15 / 03$ & 21 & -3.1 & 185 & 59 & 0.50 & 7.3 & 92.2 & 1.35 & 1.25 & 0.33 & 2.35 & 1.01 & 0.72
\end{tabular}

Figure 22.-Scaling from 72 to 21 -in.-chord with $W e_{L}$ matched. NACA 0012 airfoils; $n_{0}, 0.3 ; V_{R}, 100 \mathrm{kt} ; M V D_{R}$, $170 \mu \mathrm{m}$. 

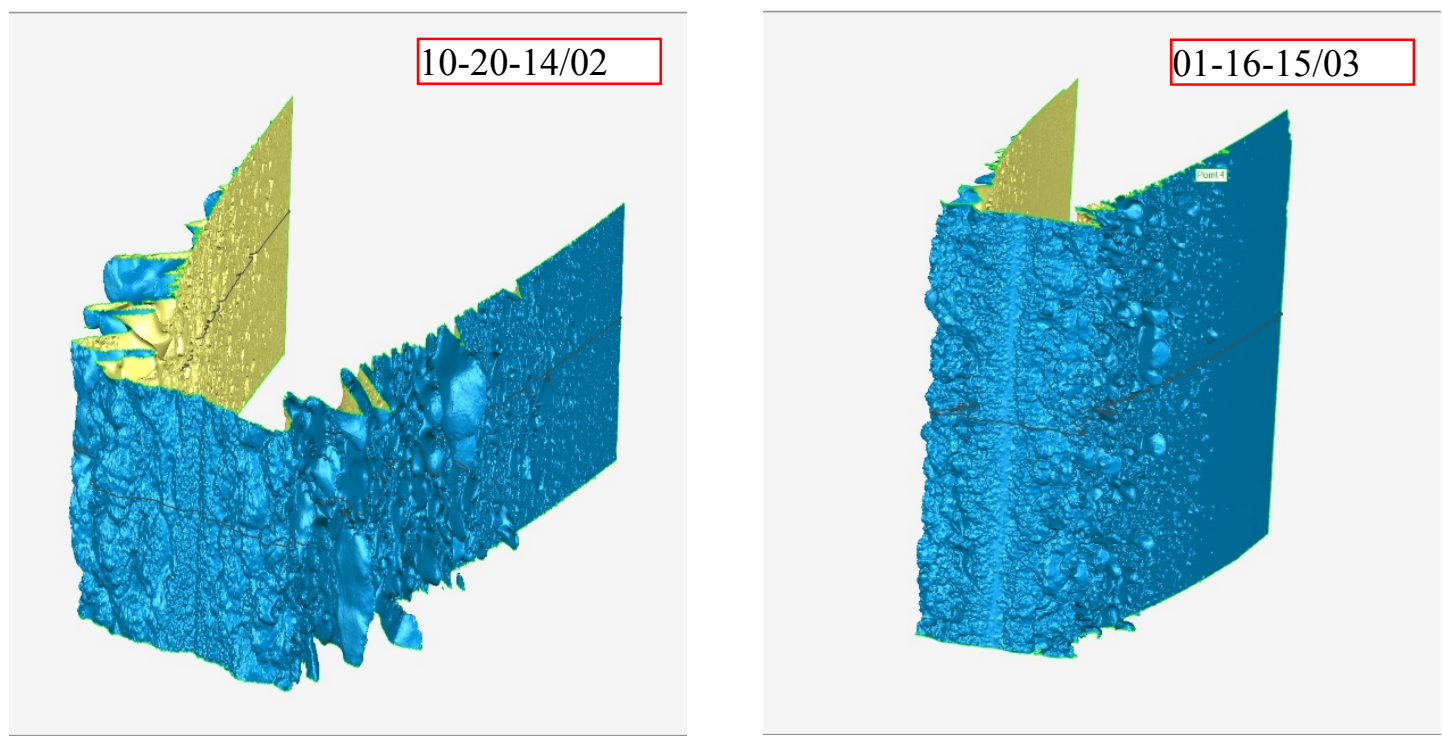

Figure 23.-The corresponding 3-D scan images of the reference and scale ice shapes shown in Figure 22.

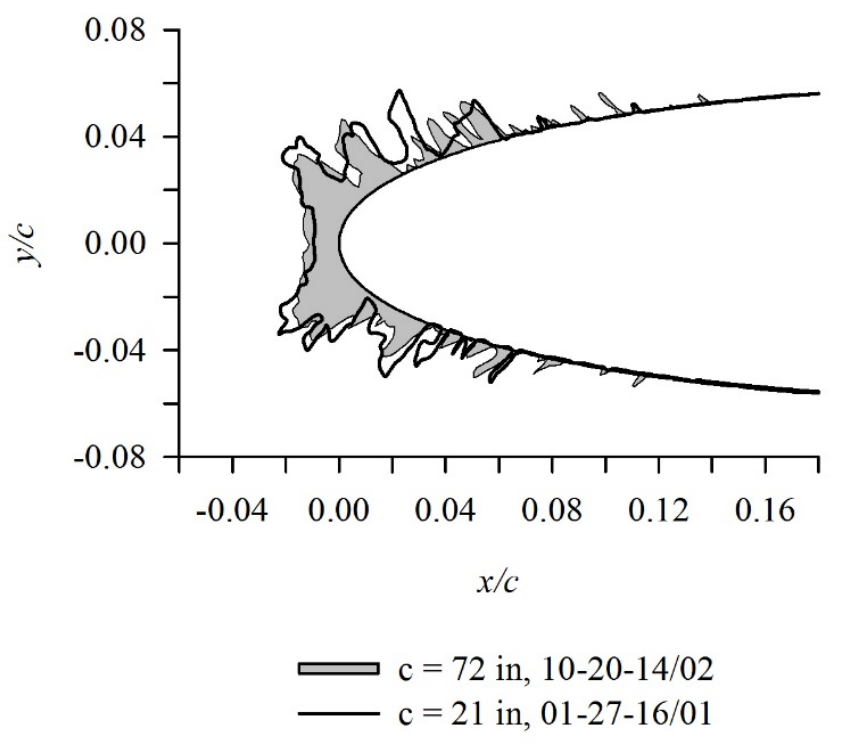

\begin{tabular}{cccccccccccccc} 
Date/Run & $\begin{array}{c}c, \\
\text { in. }\end{array}$ & $\begin{array}{c}t_{\text {tot, }}{ }^{\circ} \mathrm{C} \\
\text { kt }\end{array}$ & $\begin{array}{r}V, \\
\mathrm{kt}\end{array}$ & $\begin{array}{c}M V D, \\
\mu \mathrm{m}\end{array}$ & $\begin{array}{c}L W C, \\
\mathrm{~g} / \mathrm{m}^{3}\end{array}$ & $\begin{array}{r}\tau, \\
\mathrm{min} .\end{array}$ & $\begin{array}{c}\beta_{0}, \\
\%\end{array}$ & $A_{c}$ & $\beta_{0} A_{c}$ & $n_{0}$ & $\begin{array}{c}\mathrm{We}_{L}, \\
10^{6}\end{array}$ & $\begin{array}{c}\mathrm{We}_{f}, \\
10^{-16}\end{array}$ & $\begin{array}{c}h_{f} / d, \\
10^{-9}\end{array}$ \\
\hline $10-20-14 / 02$ & 72 & -10.8 & 99 & 171 & 1.35 & 18.6 & 92.4 & 1.45 & 1.34 & 0.30 & 2.30 & 1.10 & 0.59 \\
$01-27-16 / 01$ & 21 & -2.8 & 226 & 58 & 0.56 & 5.7 & 92.6 & 1.44 & 1.33 & 0.30 & 3.50 & 1.08 & 0.60
\end{tabular}

Figure 24.-Scaling from 72 to 21 -in.-chord with $W_{f}$ and $\left(h_{f} / d\right)$ matched. NACA 0012 airfoils; $n_{0}, 0.3 ; V_{R}, 100 \mathrm{kt}$; $M V D_{R}, 170 \mu \mathrm{m}$. 

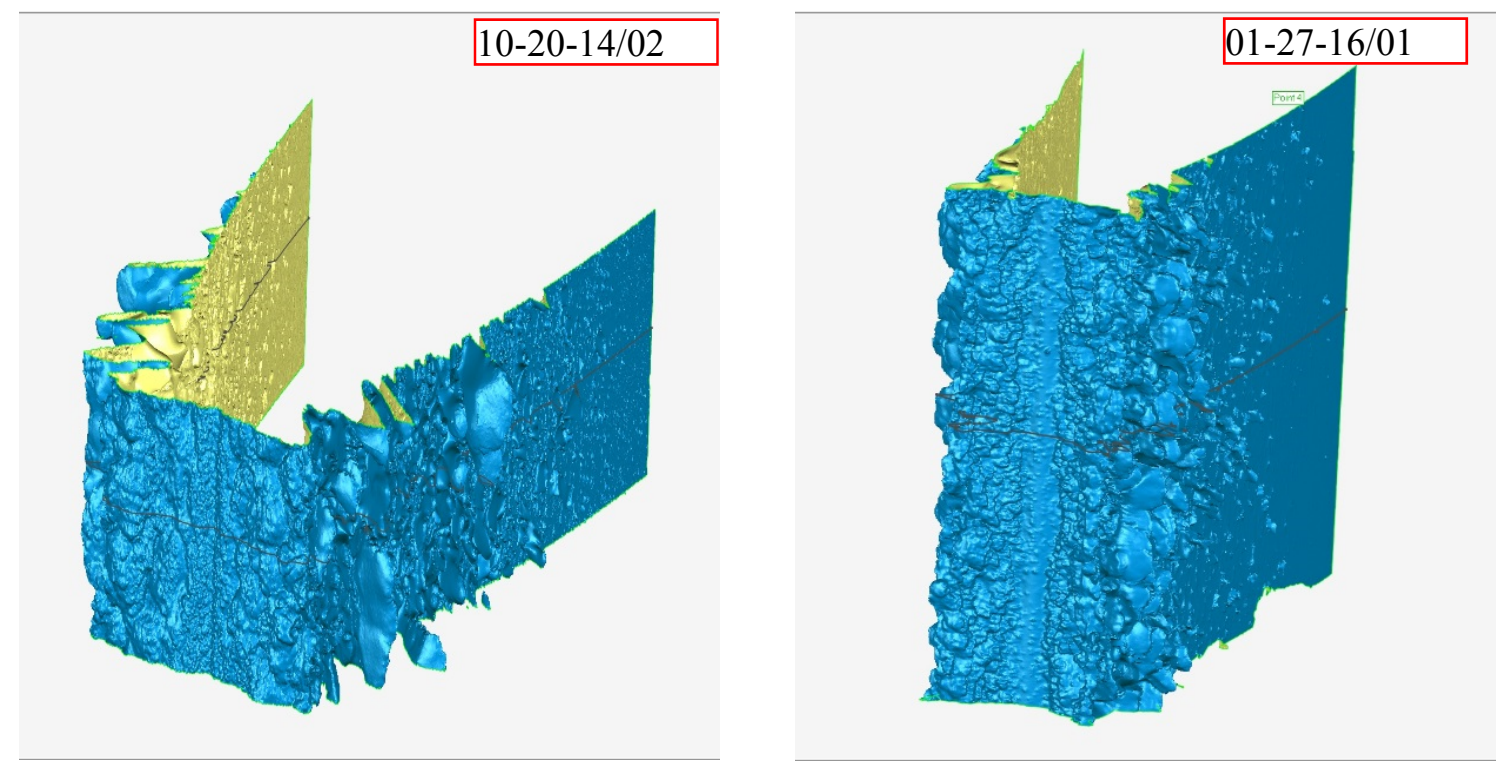

Figure 25.-The corresponding 3-D scan images of the reference and scale ice shapes shown in Figure 24.

\section{Conclusion}

SLD icing scaling tests in the NASA Glenn Icing Research Tunnel were conducted to evaluate the constant $\mathrm{We}_{L}$ and the constant $\left(\mathrm{We}_{f}\right.$ and $h / d$ ) methods in strong glaze icing conditions. The reference tests used a full-span, aluminum, 72-in.-chord NACA 0012 model with velocities of 100 and $130.3 \mathrm{knot}$ and MVD of 85 and $170 \mu \mathrm{m}$. Scale-to-reference model size ratio was 1:3.4. All tests were made at $0^{\circ}$ AOA. Results were presented for stagnation point freezing fractions of 0.2 and 0.3 .

For freezing fraction of 0.3 , the constant $\mathrm{We}_{L}$ method resulted in scale accretions better matching the shape and size of the reference. At a freezing fraction of 0.2 , the constant $\mathrm{We}_{L}$ method still resulted in providing acceptable simulations of the reference ice shape within the ice-shape repeatability, provided that the air total temperature will stay below $-2{ }^{\circ} \mathrm{C}$ when choosing the scale LWC from the Olsen method. At low freezing fractions, poorer repeatability has been observed than for higher freezing fractions. Conclusions of this study regarding the constant- $\mathrm{We}_{L}$ and constant- $\mathrm{We}_{f}$ methods of finding scale velocity agreed with those of reference (Ref. 17) and, in which any scaling method considered for glaze ice accretion has to be consistent with the presumption that both Re and We are important parameters in describing those water-film phenomena that affect ice accretion.

Given the repeatability variations encountered in the IRT for SLD conditions, it can be concluded that for SLD icing clouds in conditions where the droplet impact could interact strongly with the surface shear-driven film flow when the freezing process is slow the constant $\mathrm{We}_{L}$ method is a better choice of similarity parameter for determining scale velocity than the constant $\left(\mathrm{We}_{f}\right.$ and $\left.h / d\right)$ method at low stagnation point freezing fractions of 0.2 and 0.3 . 


\section{References}

1. Code of Federal Regulations, Title 14, Chapter 1, Federal Aviation Administration, Department of Transportation, Part 25, "Airworthiness Standards: Transport Category Airplanes," Appendix C, U.S. Government Printing Office, Washington DC, revised as of January 2010.

2. Anderson, David N., "Manual of Scaling Methods," NASA/CR-2004-212875, March 2004.

3. Anderson, D.N and Tsao, J.C., "Ice Shape Scaling for Aircraft in SLD Conditions," NASA/CR2008-215302 and DOT/FAA/AR-07/55, September 2008.

4. Anderson, David N., "A Preliminary Study of Ice-Accretion Scaling for SLD Conditions," AIAA-2002-0521, January 2002.

5. Anderson, David N. and Tsao, J.C., "Additional Results of Ice-Accretion Scaling at SLD Conditions," AIAA-2003-0390, January 2003.

6. Tsao, J.C. and Kreeger, Richard E., "Evaluation of Scaling Methods for Rotorcraft Icing," NASA/TM-2010-215801.

7. Tsao, J.C., Kreeger, R.E. and Feo, A., "Evaluation of the Water Film Weber Number in Glaze icing Scaling," NASA/TM-2010-216101.

8. Tsao, J.C. and Lee, S., "Evaluation of Icing Scaling on Swept Wing NACA 0012 Airfoil Models,"NASA/CR-2012-217419.

9. Bilanin, A.J., "Proposed Modifications to the Ice Accretion/Icing Scaling Theory," AIAA Paper AIAA-88-0203, January 1988.

10. Bilanin, Alan J. and Anderson, David N., "Ice Accretion with Varying Surface Tension," AIAA-95-0538 and NASA TM 106826, January 1995.

11. Kind, R.J., Dillon, T., Gaydos, J.A. and Oleskiw, M., "Evidence for the Importance of Scaling Viscous Effects in the Water Film in Glaze Icing Tests," AIAA-98-0196, January 1998.

12. Anderson, David N. and Ruff, Gary A., "Evaluation of Methods to Select Scale Velocities in Icing Scaling Tests," AIAA-99-0244, January 1999.

13. Anderson, David N., "Effect of Velocity in Icing Scaling Tests," AIAA-2000-0236, January 2000.

14. Mundo, C., Sommerfeld, M. and Tropea, C., "Droplet-Wall Collisions: Experimental Studies of the Deformation and Breakup Process," Int. J. Multiphase Flow, vol. 21, no. 2, 1995, pp. 151-173.

15. Feo, A. and Urdiales, M., "Stagnation Point Probe in a Water Spray Immersed in an Airstream," $\phi A E / T N O / 0452 / 003 / I N T A / 95$, Instituto Nacional de Técnica Aeroespacial, February 1995.

16. Feo, A., "Icing Scaling with Surface Film Thickness Similarity for High $L W C$ Conditions," AE/PRO/4420/184/INTA/00, Instituto Nacional de Técnica Aeroespacial, October 2000.

17. Anderson, David N. and Feo, Alejandro, "Ice-Accretion Scaling Using Water-Film Thickness Parameters," AIAA-2002-0522, January 2002.

18. Feo, A. and Tsao, J.C., "The Water Film Weber Number in Glaze Icing Scaling," SAE Aircraft \& Engine Icing International Conference, SAE-2007-01-3295, September 24-27, 2007.

19. Tsao, J.C., Kreeger, R.E. and Feo, A., "Evaluation of the Water Film Weber Number in Glaze icing Scaling," AIAA-2009-4129, June 2009.

20. Feo, A., "Similarity of Water Film Weber Number and Film Thickness in Icing Scaling," AE/TNO/4420/264/INTA/01, Instituto Nacional de Técnica Aeroespacial, October 2001.

21. Feo, A. and Urdiales, M. Circular Cylinder Film Thickness Measurements Due to an Incident Water Spray. AE/TNO/4420/363/INTA/04. July 2004.

22. A. Experimental Similarity Results Using a Stagnation Point Probe for a Limited Number of SLD conditions. Presented at NASA/INTA Meeting on Icing Physics Research. Cleveland, Ohio. November 2005.

23. Ruff, G.A., "Analysis and Verification of the Icing Scaling Equations," AEDC-TR-85-30, vol. 1 (rev), March 1986.

24. Langmuir, Irving and Blodgett, Katharine B. "A Mathematical Investigation of Water Droplet Trajectories,” Army Air Forces Technical Report No. 5418, February 1946. 
25. Abbott, Ira H. and von Doenhoff, Albert E., Theory of Wing Sections, Dover, New York, 1959, pp. 114 and 321.

26. Messinger, B.L., "Equilibrium Temperature of an Unheated Icing Surface as a Function of Airspeed,” J. Aeron. Sci., vol. 20 no. 1, January 1953, pp 29-42.

27. Tribus, Myron, Young, G.B.W. and Boelter, L.M.K., "Analysis of Heat Transfer Over a Small Cylinder in Icing Conditions on Mount Washington," Trans. ASME, vol. 70, November 1948, pp 971-976.

28. Charpin, Francois and Fasso, Guy, "Essais de givrage dans la grande soufflerie de Modane sur maquettes a echelle grandeur et echelle reduite," L'Aeronautique et l'Astronautique, no. 38, 1972, pp 23-31. English translation published as "Icing Testing in the Large Modane Wind-Tunnel on Full-Scale and Reduced Scale Models," NASA TM-75373, March 1979.

29. Anderson, David N. and Tsao, J.C., "Additional Results of Ice-Accretion Scaling at SLD Conditions," AIAA-2003-0390, January 2003 and NASA/CR-2005-213850, August 2005.

30. Bartlett, C. Scott, "An Analytical Study of Icing Similitude for Aircraft Engine Testing," DOT/FAA/CT-86/35 and AEDC-TR-86-26, October 1986.

31. Bartlett, C. Scott, "Icing Scaling Considerations for Aircraft Engine Testing," AIAA-88-0202, January 1988.

32. Oleskiw, Myron M., De Gregorio, Fabrizio and Esposito, Biagio, "The Effect of Altitude on Icing Tunnel Airfoil Icing Simulation," Proceedings of the FAA International Conference on Aircraft Inflight Icing, DOT/FAA/AR-96/81,II, August 1996, pp 511-520.

33. Van Zante, Judith F., Ide, Robert F., and Steen, Laura E., "NASA Glenn Icing Research Tunnel: 2012 Cloud Calibration Procedure and Results," AIAA-2012-2933, June 2012.

34. Van Zante, Judith F., Ide, Robert F., Steen, Laura E. and Acosta, Waldo J., "NASA Glenn Icing Research Tunnel: 2014 Cloud Calibration Procedure and Results,” NASA/TM-2014-218392, October 2014.

35. Steen, Laura E., Ide, Robert F. and Van Zante, Judith F., "An Assessment of the SEA MultiElement Sensor for Liquid Water Content Calibration of the NASA GRC Icing Research Tunnel," Oral presentation, The SAE 2015 International Conference on Icing of Aircraft, Engines and Structures, 22-25 June 2015, Prague, the Czech Republic.

36. Rigby, D.L., Struk, P.M., and Bidwell, C., "Simulation of fluid flow and collection efficiency for an SEA multi-element probe," AIAA-2014-2752, June 2014.

37. http://www.geomagic.com.

38. http://www.rhino3d.com. 

